Clim. Past Discuss., doi:10.5194/cp-2016-31, 2016

Manuscript under review for journal Clim. Past

Published: 17 March 2016

(c) Author(s) 2016. CC-BY 3.0 License.

\title{
Disentangling the effect of ocean temperatures and isotopic content on the oxygen - isotope signals in the North Atlantic Ocean during Heinrich Event 1 using a global climate model
}

\author{
Marianne Bügelmayer-Blaschek ${ }^{1}$, Didier M. Roche ${ }^{1,2}$, Hans Renssen ${ }^{1}$, and \\ Claire Waelbroeck ${ }^{2}$ \\ ${ }^{1}$ Earth and Climate Cluster, Faculty of Earth and Life Sciences, Vrije Universiteit Amsterdam, \\ Amsterdam, The Netherlands \\ ${ }^{2}$ Laboratoire des Sciences du Climat et de l'Environnement (LSCE), CEA/CNRS-INSU/UVSQ, \\ Gif-sur-Yvette Cedex, France \\ Correspondence to: M. Bügelmayer-Blaschek(m.bugelmayer@vu.nl)
}

Abstract. Heinrich events are intriguing episodes of enhanced iceberg discharge occurring during the last glacial period and are characterized by a steep increase in ice rafted debris (IRD) found in North Atlantic cores. Yet, their signal is not directly recognizable in the carbonate oxygen isotopic composition recorded in planktonic foraminifera, which depends on both the prevailing temperature and isotopic composition of seawater. Using the global isotope-enabled climate-iceberg model $i$ LOVECLIM we performed three experiments to shed light on first, the impact of the duration of a Heinrich event-like iceberg forcing on the North Atlantic Ocean and second, the mechanisms behind the simulated $\delta^{18} \mathrm{O}_{\text {calcite }}$ pattern. We applied an iceberg forcing of $0.2 \mathrm{~Sv}$ for 300, 600 and 900 years, respectively, and find a strong and non-linear response of the Atlantic Meridional Overturning Circulation (AMOC) to the duration of the Heinrich event in $i$ LOVECLIM. Moreover, our results show that the timing of the first response to the iceberg forcing coincides between all the experiments in the various regions and happens within 300 years. Furthermore, the experiments display two main patterns in the $\delta^{18} \mathrm{O}_{\text {calcite }}$ signal. On the one hand, the central and northeast North Atlantic regions display almost no response in $\delta^{18} \mathrm{O}_{\text {calcite }}$ to the applied iceberg forcing since the changes in sea surface temperature and $\delta^{18} \mathrm{O}_{\text {seawater }}$ compensate each other or, if the forcing is applied long enough, a delayed response is seen. On the other hand, we show that in Baffin Bay, the Nordic Seas and the subtropical North Atlantic the change in $\delta^{18} \mathrm{O}_{\text {seawater }}$ exceeds the sea surface temperature signal and there the $\delta^{18} \mathrm{O}_{\text {calcite }}$ pattern closely follows the $\delta^{18} \mathrm{O}_{\text {seawater }}$ signal and displays a continuous decrease over the length of the Heinrich event with the minimum value at the end of the iceberg release. The comparison of the model experiments with four marine sediment cores indicates that the experiment with an iceberg forcing of $0.2 \mathrm{~Sv}$ for 300 years yields the most reasonable results. 
Clim. Past Discuss., doi:10.5194/cp-2016-31, 2016

Manuscript under review for journal Clim. Past

Published: 17 March 2016

(c) Author(s) 2016. CC-BY 3.0 License.

\section{Introduction}

The current climatic warming is causing accelerated mass loss from the Greenland and Antarctic ice sheets (e.g. Rignot et al., 2011), producing enhanced runoff and iceberg calving, and increased freshwater fluxes into the oceans (e.g. Vizcaíno et al., 2008). In the Northern Hemisphere, higher freshwater fluxes might weaken the Atlantic Meridional Overturning Circulation (AMOC), thus altering the global climate (Manabe and Stouffer, 1995; Ganopolski and Rahmstorf, 2001). The interactions between freshwater fluxes and the AMOC are however complex, since the AMOC's response depends among other things on the amount and the exact location of the added freshwater fluxes (Roche et al., 2004; Swingedouw et al., 2009; Smith and Gregory, 2009). This complexity has been addressed in numerous studies using either numerical models, or proxy data or a combination of the two methods (e.g. Stommel, 1961; Manabe and Stouffer, 1995; Rahmstorf, 2002; Stouffer et al., 2006; Roche et al., 2010).

Proxy data have provided convincing evidence of rapid climate changes in the past that were related to a slowdown or even shut-down of the AMOC (Broecker et al., 1985). Proxy data, such as collected in ocean cores, provide information about the ocean's state during past times. For example, the isotopic analysis of benthic (bottom dwelling) and planktonic (surface dwelling) foraminifera gives information on the temperature and isotopic composition of seawater during the formation of their shells (Urey, 1947; Shackleton, 1974). Furthermore, knowledge about the ocean's ventilation can be gathered from benthic foraminifera ${ }^{13} C$ (Lynch-Stieglitz et al., 1995) and the strength of the ocean circulation can be estimated from the sedimentary protactinium-thorium ratio $(\mathrm{Pa} / \mathrm{Th}$, Yu et al., 1996; Balcerak, 2011). Unfortunately, these proxies do not only react to changes in ocean circulation, but also to changes in biological productivity (in the case of benthic foraminifera $\delta^{13} C$, LynchStieglitz et al., 1995) or to changes in particle fluxes (in the case of $\mathrm{Pa} / \mathrm{Th}$, Geibert and Usbeck, 2004) complicating the interpretation of the recorded signal. Nevertheless, they provide valuable insight into past climate conditions and changes, such as a strong reduction in oceanic circulation during Heinrich stadial 1 (HS1), that is the time period between $\sim 17.5$ calendar ky BP (ka) and the transition towards the Bolling-Allerod warm interval at $14.7 \mathrm{ka}$ (McManus et al., 2004; Gherardi et al., 2005, 2009).

50 Heinrich events are specific episodes during which large armadas of icebergs were released from the Northern Hemisphere ice sheets, leading to widespread sedimentation of ice-rafted debris (IRD) across the high-to-mid latitude North Atlantic Ocean (e.g. Andrews et al., 2000; Hemming, 2004). Heinrich events are thus characterized by a steep increase of ice rafted debris in North Atlantic sediment cores and six of those events were identified during the last glacial cycle (Heinrich, 1988). IRD is defined as sediment coming from ice sheets and transported by sea ice and icebergs. The quantity of IRD of a certain grain size fraction (e.g. $<63 \mu \mathrm{m}$, Andrews et al., 2000) in one core is taken as an indication of the amount of icebergs that floated over the core site. Furthermore, the 
Clim. Past Discuss., doi:10.5194/cp-2016-31, 2016

Manuscript under review for journal Clim. Past

Published: 17 March 2016

(c) Author(s) 2016. CC-BY 3.0 License.

analysis of Northern-Hemisphere proxies indicates that Heinrich events coincide with cold climate conditions and a weakened AMOC (Hemming, 2004).

IRD records provide a clear signal of the occurrence of Heinrich events. Yet, the interpretation is not as straightforward for the carbonate oxygen isotopic composition recorded in planktonic foraminifera because it depends on both the prevailing temperature and isotopic composition of seawater. The cooling of the surface ocean on the one hand, the freshening and the associated depletion of the seawater on the other hand, might cancel each other out or delay the signal in the $\delta^{18} \mathrm{O}_{\text {calcite }}$. Using an isotope-enabled climate model, Roche and Paillard (2005) investigated the contribution of these two effects to the $\delta^{18} \mathrm{O}_{\text {calcite }}$ signal. They showed that as a result of the competing effects, the modeled $\delta^{18} \mathrm{O}_{\text {calcite }}$ at the location of the ocean core MD95-2042 displays a weaker signal during Heinrich event 4 ( $\sim 40 \mathrm{ka}$ ) than expected, which fits reasonably to the corresponding proxy data (Shackleton et al., 2000; Roche and Paillard, 2005).

70 Overall, it has proven difficult to constrain the duration and amount of released freshwater during Heinrich events. However, climate models are helpful tools for this purpose. Estimates derived from proxy data and climate models range from 250 to more than 1250 years with yearly iceberg melt fluxes of 0.04 Sv to 0.4 Sv (1 Sv $=10^{6} \mathrm{~m}^{3} \mathrm{~s}^{-1}$, Hemming, 2004; Roche et al., 2004; Levine and Bigg, 2008; Green et al., 2011; Jongma et al., 2013; Roberts et al., 2014). In particular, Roche et al. (2004) showed that the most likely scenario for Heinrich event 4 was a duration of $250 \pm 150$ years with a meltwater flux of $0.29 \pm 0.05 \mathrm{~Sv}$ using a climate model with an isotope-enabled ocean model. Recently, Roche et al. (2014) found that the best fit between modeled and observed $\delta^{18} \mathrm{O}_{\text {calcite }}$ of Heinrich event $1(\sim 17.5 \mathrm{ka})$ is achieved when the AMOC is strongly weakened, but not completely shut down. These authors used an isotope-enabled climate model to perform hosing experiments, thus adding the freshwater related to iceberg discharge directly to the ocean, and compared the simuated $\delta^{18} \mathrm{O}_{\text {calcite }}$ of the model with proxy data at various ocean depths. Moreover, they showed that the best agreement between model and data is found when freshwater is added in the Labrador Sea, thus mimicking icebergs calved from the Laurentide ice sheet rather than dumping the water in the Ruddiman belt $\left(40^{\circ}-55^{\circ} \mathrm{N}\right.$, Ruddiman, 1977) as has been done before (e.g. Schmittner et al., 2002; Timmermann et al., 2005; Hewitt et al., 2006). Another approach to constrain the freshwater flux released during Heinrich events was taken by Roberts et al. (2014), who simulated the sediments discharge of icebergs using an active iceberg model to mimic the IRD found in ocean cores. Their set-up indicates a much weaker freshwater flux of $0.04 \mathrm{~Sv}$ over 500 years than expressed by previous studies, but the authors notice that the total volume released is similar to the one obtained by Roche et al. (2004).

Other modelling studies have concentrated on explicitly simulating the impact of icebergs on climate during Heinrich events (Levine and Bigg, 2008; Green et al., 2011; Jongma et al., 2013). These studies found that simulating Heinrich events using a climate model with an implemented interactive iceberg model results in a different AMOC response compared to hosing experiments. 
Clim. Past Discuss., doi:10.5194/cp-2016-31, 2016

Manuscript under review for journal Clim. Past

Published: 17 March 2016

(c) Author(s) 2016. CC-BY 3.0 License.

Hosing experiments ignore the take up of latent heat needed to melt the icebergs and underestimate the spread of the meltwater anomaly. Both effects cause a different ocean state than directly applying freshwater fluxes (e.g. Jongma et al., 2009; Bügelmayer et al., 2015a).

To summarize, the modeling approaches taken so far either concentrated on determining the duration and freshwater fluxes by comparing the modeled isotope or IRD values with proxy data (Roche et al., 2004, 2014; Roberts et al., 2014) or on the explicit computation of the icebergs' effect on the ocean's state (Levine and Bigg, 2008; Green et al., 2011; Jongma et al., 2013). In the present study we combine the two approaches of isotopic modeling and interactively computed icebergs by using a global isotope-enabled climate - iceberg model. We concentrate on Heinrich Event 1 ( 17.5-14.7 ka), thereby extending the work of Roche et al. (2014), who showed that the freshwater flux that yields model results in best agreement with available proxy data evidence is $0.2 \mathrm{~Sv}$. Moreover, it allows us to use their tested and described background state of the Last Glacial Maximum (LGM, 21 ka, Roche et al., 2014).

Using the $i$ LOVECLIM climate model we aim to investigate the following research questions:

(1) what is the impact of the duration of the iceberg discharge on the climate's response? (2) To what extent does the simulated signal in $\delta^{18} \mathrm{O}_{\text {calcite }}$ during Heinrich event 1 depend on its location? (3) How do the changes in ocean temperatures and $\delta^{18} \mathrm{O}_{\text {seawater }}$ caused by the iceberg discharge and related changes in ocean circulation impact the $\delta^{18} \mathrm{O}_{\text {calcite }}$ recorded in proxies?

\section{Methods}

\section{1 iLOVECLIM climate model}

115 The climate model $i$ LOVECLIM version 1.0 is an earth system model of intermediate complexity and a code fork of the LOVECLIM 1.2 model (Goosse et al., 2010). iLOVECLIM has been further developed to include the explicit computation of water isotopes in the atmosphere, ocean, continental surface (Roche, 2013) and icebergs. Following the description of Bügelmayer et al. (2015a) we state the main characteristics of the ocean, atmosphere and vegetation models.

The included atmospheric model ECBilt (Opsteegh et al., 1998) is a quasi-geostrophic, spectral model calculated with a time step of 4 hours on a horizontal $\mathrm{T} 21$ truncation $\left(5.6^{\circ}\right.$ in latitude/longitude) and three vertical pressure levels $(800,500,200 \mathrm{hPa})$. The cloud cover is prescribed according to climatology (ISCCP D2 dataset, Rossow et al., 1996) and precipitation is only computed in the lower most (tropospheric) layer and is obtained using the available humidity at this level. To compute the soil moisture, a simple bucket model is implemented that takes into account evaporation, precipitation and snow melt. If the water content exceeds a defined threshold, the excess water is automatically transported as runoff to the corresponding ocean grid point. The sea-ice and ocean component CLIO consists of a dynamic - thermodynamic sea-ice model (Fichefet and Maqueda, 1997, 1999) coupled to a 3D ocean general circulation model (Deleersnijder and Campin, 1995; Deleersnijder 
Clim. Past Discuss., doi:10.5194/cp-2016-31, 2016

Manuscript under review for journal Clim. Past

Published: 17 March 2016

(c) Author(s) 2016. CC-BY 3.0 License.

et al., 1997; Campin and Goosse, 1999). The discretization is done on an approximately $3^{\circ} \times 3^{\circ}$ in longitude and latitude and presents 20 unevenly spaced vertical levels in the ocean. The formulation of the surface albedo of the sea ice takes into account its state (frozen or melting) and the thickness of the snow and ice covers (Goosse et al., 2010). The ocean model has a free surface allowing the use of real freshwater fluxes and a realistic bathymetry. The vegetation model used is VECODE (Brovkin et al., 1997) that accounts for two plant functional types (trees and grass) and bare soil as a dummy type. It has the same resolution as the atmospheric model, but allows fractional use of one grid cell to consider small spatial changes in vegetation. It depends on the temperature and precipitation provided by ECBilt and accounts for long-term (decadal to centennial) changes of the climate.

Icebergs are computed using the optional dynamic - thermodynamic iceberg module included in $i$ LOVECLIM (Jongma et al., 2009; Wiersma and Jongma, 2010), which is based on the icebergdrift model of Smith and co-workers (Smith and Banke, 1983; Smith, 1993; Løset, 1993) and on the developments done by Bigg et al. $(1996,1997)$ and Gladstone et al. (2001). According to the provided ice mass icebergs of 10 size classes are generated at the pre-defined calving locations following the size distribution presented by Bigg et al. (1996) and based on present day observations (Dowdeswell et al., 1992). We do not expect to introduce a strong bias due to the use of the presentday distribution under LGM conditions, because the chosen size classes only have a marginal impact on the resulting ocean state (Bügelmayer et al., 2015b). Icebergs are moved by the Coriolis force, the air-, water-, and sea-ice drag, the horizontal pressure gradient force and the wave radiation force. The icebergs melt over time due to basal melt, lateral melt and wave erosion and may roll over as their length to height ratio changes. The heat needed to melt the icebergs is taken from the ocean layers corresponding to the icebergs' depth, and their meltwater fluxes are put into the ocean surface layer of the current grid cell. The refreezing of melted water and the break-up of icebergs are not included in the iceberg module.

In ECBilt water isotopes are treated in the same way as moisture to ensure consistency between freshwater fluxes and isotopic fluxes (Roche, 2013). In CLIO water isotopes are handled as passive tracers. In the current set-up, isotopes have also been added to the iceberg module with a fixed value of $-30 \%$ ochosen to mimic the depletion of the ice-sheet source and the exact value chosen is not important for the current study. The freshwater flux and the water isotopes are accordingly added to the oceans' surface layer when the icebergs melt.

\subsection{Experimental set-up}

Using the $i$ LOVECLIM model, Roche et al. (2014) found the best agreement between simulated and observed $\delta^{18} \mathrm{O}_{\text {calcite }}$ of Heinrich event 1 when applying a strong freshwater forcing of about $0.2 \mathrm{~Sv}$ over 300 years. This value depends of course on the model and the duration of the applied forcing. 
Clim. Past Discuss., doi:10.5194/cp-2016-31, 2016

Manuscript under review for journal Clim. Past

Published: 17 March 2016

(c) Author(s) 2016. CC-BY 3.0 License.

Moreover, the modeled $\delta^{18} \mathrm{O}_{\text {calcite }}$ fits better to proxy data when the freshwater forcing was applied in the Labrador Sea than when added in the Ruddiman belt (Roche et al., 2014).

We therefore use a similar set-up as Roche et al. (2014) and generate icebergs of a total volume of $1.7 * 10^{10} \mathrm{~m}^{3}$ year ${ }^{-1}$, which corresponds to a $0.2 \mathrm{~Sv}$ freshwater flux. The icebergs are released in the Labrador Sea (Figure 1). We performed three experiments, all started from the same initial conditions as described in (Roche et al., 2014), but conducted over different lengths to test the impact of the duration of the iceberg release on the oceanic conditions. First, we performed the so-called ICE-300 experiment where we released an iceberg flux of $0.2 \mathrm{~Sv}$ for 300 years; second, the ICE-600 where the iceberg flux of $0.2 \mathrm{~Sv}$ was applied for 600 years; and third, the ICE-900 with an iceberg flux of $0.2 \mathrm{~Sv}$ for 900 years. All the experiments were started from the same initial conditions and the first 100 years were modeled without icebergs and are further used as a control state. After the iceberg forcing stopped, the experiments were conducted for another 600 years, thus the ICE-300 was integrated over a total of 1,000 years, ICE-600 over 1,300 model years and ICE-900 over 1,600 model years.

\section{Results}

\subsection{Climate response to iceberg forcing}

The AMOC strength is greatly weakened in all experiments, independently of the duration of the applied iceberg flux (Figure 2). This reduction is related to the weakening of the deep convection by the melting icebergs, especially in the Labrador and Greenland - Iceland - Norwegian (GIN) Seas. After 300 years of iceberg melt flux, the AMOC is strongly reduced, but not shut down. This is also seen in the fact that it starts to recover in ICE-300 as soon as the iceberg discharge stops (Figure 2, green line). In ICE-600 and ICE-900 however, the persistent supply of icebergs causes the AMOC to shut down, therefore it needs another 700 years until it starts to recover in ICE-600 and 2,200 years in ICE-900 (not shown). This demonstrates that in $i$ LOVECLIM the ability of the AMOC to recover from a Heinrich event-like iceberg discharge is non-linear and strongly depends on the duration of the applied freshwater fluxes.

The duration of the iceberg release impacts the maximum amplitude of the oceanic changes, but the timing of the first response in sea surface temperature (SST), $\delta^{18} \mathrm{O}_{\text {seawater }}$ and $\delta^{18} \mathrm{O}_{\text {calcite }}$ is identical in all the experiments and happens within the first 300 years of iceberg discharge. Therefore, only the results of the ICE-300 set-up are shown in Figure 3. As expected, the change in SST, $\delta^{18} \mathrm{O}_{\text {seawater }}$ and $\delta^{18} \mathrm{O}_{\text {calcite }}$ caused by the icebergs is immediate at the calving locations and in the Ruddiman belt (Figure 3) due to the strong iceberg melt flux (IMF). In these areas, SST and $\delta^{18} \mathrm{O}_{\text {seawater }}$ decrease significantly within $0-2$ years of the icebergs release, which is also seen in $\delta^{18} \mathrm{O}_{\text {calcite }}$ (Figure 3). Other regions, such as the Greenland Sea or the Arctic Ocean respond up to 70 years after the start of the iceberg discharge due to the slow advection of the icebergs meltwater 
Clim. Past Discuss., doi:10.5194/cp-2016-31, 2016

Manuscript under review for journal Clim. Past

Published: 17 March 2016

(c) Author(s) 2016. CC-BY 3.0 License.

into these regions. Overall the timing of the $\delta^{18} \mathrm{O}_{\text {calcite }}$ signal is closer to timing of the SST than of $\delta^{18} \mathrm{O}_{\text {seawater }}$ signal, which indicates the stronger impact of SST on the $\delta^{18} \mathrm{O}_{\text {calcite }}$ signal (Figure 3). However, in Baffin Bay the $\delta^{18} \mathrm{O}_{\text {seawater }}$ is significantly altered by the depleted IMF within 10 years, as also seen in $\delta^{18} \mathrm{O}_{\text {calcite }}$, yet the SST does not display any change or only after up to 70 years. This is due to the prevailing cold conditions and to the presence of sea ice in Baffin Bay (Figure 4b, e), which prevent the SST to strongly react to the IMF.

All the experiments display the maximum IMF in the Labrador Sea due to the located calving sites (Figure 1) and in the Ruddiman belt (Figure 5, Figure 6, Figure 7,a). In the latter area, we also find the minimum sea surface temperatures (Figure 5, Figure 6, Figure 7, b) at the end of the iceberg release caused by the combination of the icebergs cooling effect and the reduced ocean circulation (Figure 5, Figure 6, Figure 7, c). In iLOVECLIM, the major convection sites are situated in the Labrador Sea and Nordic Seas, southeast of the sea ice margin (Figure 4a, c; CLD=convection layer depth) during LGM conditions, as in other studies (e.g. Dokken and Jansen, 1999; Seidov and Maslin, 1999; Hewitt et al., 2001). The IMF strongly impacts the deep convection in the Labrador Sea and also in the Nordic Seas, especially in ICE-600 and ICE-900. The location and magnitude of the strongest change in SST is almost identical in all three experiments, but in ICE-600 and ICE-900 the longer duration of the freshwater forcing causes a wider spread cooling than seen in ICE-300 (Figure 5, Figure 6, Figure 7, b). Also the locations of the minimum $\delta^{18} \mathrm{O}_{\text {seawater }}$ at the end of the freshwater flux coincide within the experiments (Figure 5, Figure 6, Figure 7,d) as it decreases greatly at and close to the calving locations in the Labrador Sea. Furthermore, the advection of

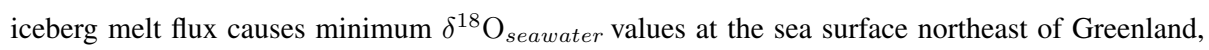
especially in ICE-600 and ICE-900 (Figure 5, Figure 6, Figure 7,d). The response in sea surface salinity greatly varies between the three experiments south of $45^{\circ} \mathrm{N}$ and in the Nordic Seas (Figure 5, Figure 6, Figure 7,e). In these two regions ICE-600 and ICE-900 show much stronger reductions in SSS than ICE-300 at the end of the iceberg discharge because there the decrease is mainly caused by the advection of the fresh surface waters rather than by the amount of icebergs reaching these areas, which is comparable in all three experiments.

Also, the $\delta^{18} \mathrm{O}_{\text {seawater }}$ and the $\delta^{18} \mathrm{O}_{\text {calcite }}$ signal in the North Atlantic and the Nordic Seas (Figure 5, Figure 6, Figure 7,d,f) vary between the three set-ups. ICE-300 displays positive $\delta^{18} \mathrm{O}_{\text {calcite }}$ values south of $45^{\circ}$ North and in the Nordic Seas, but in ICE-600 these are limited to a small region in the North Atlantic and the ICE-900 run displays purely negative values (Figure 5, Figure 6, Figure 7,f). The lower $\delta^{18} \mathrm{O}_{\text {seawater }}$ and $\delta^{18} \mathrm{O}_{\text {calcite }}$ signals in ICE-600 and ICE-900 result from the combined effect of the isotopically depleted iceberg melt flux directly released by the icebergs and the slow advection of fresh surface waters into the Nordic Seas and further south (Figure 5, Figure 6, Figure $7, \mathrm{e})$.

235 To summarize, in our model, the length of the iceberg discharge (300, 600 or 900 years) strongly impacts the AMOC's ability to recover after the Heinrich event. However, the spatial patterns of 
Clim. Past Discuss., doi:10.5194/cp-2016-31, 2016

Manuscript under review for journal Clim. Past

Published: 17 March 2016

(c) Author(s) 2016. CC-BY 3.0 License.

the deep convection and the sea surface temperature at the end of the Heinrich event-like iceberg release coincide well within the three experiments. Yet, the response in sea surface salinity, $\delta^{18} \mathrm{O}_{\text {seawater }}$ and $\delta^{18} \mathrm{O}_{\text {calcite }}$ depends on the duration of the iceberg release, especially in the North Atlantic. Moreover, we find an immediate response in $\delta^{18} \mathrm{O}_{\text {calcite }}$ to the iceberg release at the calving sites and in the North Atlantic, but it takes more than 100 years to cause a significant change in regions further away from the calving sites.

As a next step, we analyze in detail the evolution in $\delta^{18} \mathrm{O}_{\text {calcite }}$ over the course of a Heinrich event in the regions of largest negative SST and $\delta^{18} \mathrm{O}_{\text {seawater }}$ anomalies, since $\delta^{18} \mathrm{O}_{\text {calcite }}$ is primarily impacted by these two variables (Shackleton, 1974). As described above, the minimum SSTs are found in the North Atlantic due to the combination of IMF and decreased convection layer depth, the areas of minimum $\delta^{18} \mathrm{O}_{\text {seawater }}$ are on the one hand in Baffin Bay, at the calving sites, and on the other hand in the Nordic Seas, due to the advection of depleted surface waters.

\subsection{Minimum SST - its effect on the $\delta^{18} \mathrm{O}_{\text {calcite }}$ evolution}

Concentrating on the Central North Atlantic region as defined in Figure 8, which displays the minimum SSTs in all three experiments, independently of the duration of the iceberg release (300 vs 600 vs 900 years), we see that the time evolution of the IMF clearly displays a high, but slightly varying flux (1000 to $1200 \mathrm{~m}^{3} \mathrm{~s}^{-1}$, Figure 9a). This region experiences high IMF values because most icebergs are transported there and the ocean conditions cause them to melt. The values are similar in all three experiments, but the response in ocean temperature and $\delta^{18} \mathrm{O}_{\text {seawater }}$ clearly differ (Figure 9a). Concerning the SSTs, a cooling of about $6-7^{\circ} \mathrm{C}$ is seen in all three experiments, but in ICE-300 the SST increases towards its initial value as soon as the freshwater forcing stops (Figure 9a), which is not the case in ICE-600 or ICE-900 due to the severely disturbed AMOC. The signal in $\delta^{18} \mathrm{O}_{\text {seawater }}$ reflects the input of the isotopically depleted iceberg melt water $(-30 \%$ ) that causes a decrease in $\delta^{18} \mathrm{O}_{\text {seawater }}$ of $1.6 \%$ (ICE-300) to 2.5\%o(ICE-900). The $\delta^{18} \mathrm{O}_{\text {calcite }}$ signal reflects both the temperature and $\delta^{18} \mathrm{O}_{\text {seawater }}$ signal. Therefore, in ICE-300 and during the first 300 years of freshwater input in ICE-600 and ICE-900 the Heinrich event is characterized by an increase in $\delta^{18} \mathrm{O}_{\text {calcite }}$ at the beginning of the forcing. This is caused by the decrease in temperature and displays the counteracting effects of the temperature and $\delta^{18} \mathrm{O}_{\text {seawater }}$ (Figure $9 \mathrm{a}$ ). $\delta^{18} \mathrm{O}_{\text {calcite }}$ decreases towards its initial value when SST and $\delta^{18} \mathrm{O}_{\text {seawater }}$ recover. Also the ICE-600 and ICE-900 display the increase in $\delta^{18} \mathrm{O}_{\text {calcite }}$ at the beginning of the iceberg release, yet, the continuous supply of low $\delta^{18} \mathrm{O}_{\text {seawater }}$ results in a stronger decrease of $\delta^{18} \mathrm{O}_{\text {seawater }}$ than in ICE-300, which causes the $\delta^{18} \mathrm{O}_{\text {calcite }}$ to decrease again after about 300 years of freshwater pulse (Figure 9a). Both the sea surface salinity and $\delta^{18} \mathrm{O}_{\text {seawater }}$ reach their minimum towards the end of the iceberg release and increase slightly afterwards without returning to their initial value due to the presence of depleted melt water and reduced deep overturning. 
Clim. Past Discuss., doi:10.5194/cp-2016-31, 2016

Manuscript under review for journal Clim. Past

Published: 17 March 2016

(c) Author(s) 2016. CC-BY 3.0 License.

We therefore conclude that at the location of minimum SST, the signal in $\delta^{18} \mathrm{O}_{\text {calcite }}$ can on the one hand display an increase and a stable phase over the length of the Heinrich event due to the competing effects of the decreasing temperature and $\delta^{18} \mathrm{O}_{\text {seawater. }}$ On the other hand, if the freshwater pulse is applied long enough, the initial increase is followed by a decrease as soon as the amplitude of the decreased $\delta^{18} \mathrm{O}_{\text {seawater }}$ exceeds the drop in temperature.

\subsection{Minimum $\delta^{18} \mathrm{O}_{\text {seawater }}$ - its effect on the $\delta^{18} \mathrm{O}_{\text {calcite }}$ evolution}

As expected at the calving sites, the IMF is constant and relatively high in Baffin Bay over the whole duration of the Heinrich event (Figure 9b). The take-up of heat needed by the icebergs to melt causes an immediate drop of about $1.5^{\circ} \mathrm{C}$ in temperature at the ocean's surface until it reaches its freezing point of about $-2^{\circ} \mathrm{C}$. Note that the initial rise in SST over the first 100 years is due to internal variability. The SSS responds with a continuous decrease over the length of the freshwater forcing with the minimum occurring at the end of the iceberg release (Figure $9 \mathrm{~b}$ ). The $\delta^{18} \mathrm{O}_{\text {seawater }}$ also steeply decreases as soon as the icebergs start to melt and then continues to decrease over the length of the forcing. In ICE-300, at the end of the iceberg release, the $\delta^{18} \mathrm{O}_{\text {seawater }}$ increases towards its initial value and reaches it after about 300 years. In ICE-600 and ICE-900, however, it increases by about $2 \%$ obut does not reach its initial value because the long duration of the iceberg release caused a fresher ocean state compared to before the iceberg discharge. The $\delta^{18} \mathrm{O}_{\text {seawater }}$ pattern is mimicked by the $\delta^{18} \mathrm{O}_{\text {calcite }}$, displaying the fact that the change in temperature is of smaller magnitude than that in $\delta^{18} \mathrm{O}_{\text {seawater }}$ (Figure 9b).

Due to the presence of sea ice, the IMF reaching the Nordic Seas is not larger than 10 to $25 \mathrm{~m}^{3} \mathrm{~s}^{-1}$ (Figure 9c), since the few icebergs that reach that far North are pushed southward again by the ice and the wind drag (not shown). Yet, as in Baffin Bay, the temperature quickly drops by about $3^{\circ} \mathrm{C}$ and the SSS starts to decrease because the advection of the cold and fresh surface water enhances the response in SST and SSS. The $\delta^{18} \mathrm{O}_{\text {seawater }}$ begins to drop as soon as the icebergs are released, but steepens its curve later on due to the supply of surface waters (Figure 9c). As seen in Baffin Bay, the Nordic Seas $\delta^{18} \mathrm{O}_{\text {calcite }}$ pattern closely resembles the $\delta^{18} \mathrm{O}_{\text {seawater }}$ signal (Figure 9c), except within the first 20 years of the iceberg discharge, where the strong drop in SST postpones its decrease.

We find that overall the time series of the $\delta^{18} \mathrm{O}_{\text {calcite }}$ signal is very similar between the two regions of maximum $\delta^{18} \mathrm{O}_{\text {seawater }}$ decrease, mimicking the $\delta^{18} \mathrm{O}_{\text {seawater }}$ pattern rather than the SST. However, the $\delta^{18} \mathrm{O}_{\text {seawater }}$ response at the start of the iceberg discharge depends on the mechanisms at work, where in Baffin Bay the drop is immediate due to the calving locations, while in the Nordic Seas it takes about 20 years until the cold and fresh surface waters are advected into this region.

We conclude that in regions of weak surface cooling, but strong $\delta^{18} \mathrm{O}_{\text {seawater }}$ changes, the $\delta^{18} \mathrm{O}_{\text {calcite }}$ mimics the $\delta^{18} \mathrm{O}_{\text {seawater }}$ pattern. The mechanisms causing the drop in 
Clim. Past Discuss., doi:10.5194/cp-2016-31, 2016

Manuscript under review for journal Clim. Past

Published: 17 March 2016

(c) Author(s) 2016. CC-BY 3.0 License.

$\delta^{18} \mathrm{O}_{\text {seawater }}$ (freshwater as in Baffin Bay or advection of depleted surface waters as in the Nordic Seas) determine the timing of its response at the beginning of the Heinrich event.

\subsection{How does the $\delta^{18} \mathrm{O}_{\text {calcite }}$ evolution look in other regions?}

In regions where neither the temperature nor the $\delta^{18} \mathrm{O}_{\text {seawater }}$ signal dominates, we find that the $\delta^{18} \mathrm{O}_{\text {calcite }}$ evolution can represent either a stable phase, displaying counteracting effects of SST and $\delta^{18} \mathrm{O}_{\text {seawater }}$ or mimic the $\delta^{18} \mathrm{O}_{\text {seawater }}$ (Figure 9d,e). In the Northeast North Atlantic the temperature and $\delta^{18} \mathrm{O}_{\text {seawater }}$ decrease almost balance each other in the ICE-300 experiment (Figure 9d), 315 but in ICE-600 and ICE-900 the continuous decrease in $\delta^{18} \mathrm{O}_{\text {seawater }}$ exceeds the temperature signal after about 400 years, causing a decrease in $\delta^{18} \mathrm{O}_{\text {calcite }}$, similar to the pattern seen in the central North Atlantic (Figure 9a).

Almost no IMF reaches the subtropical North Atlantic, only occasional pulses of $\sim 0.5 \mathrm{~m}^{3} \mathrm{~s}^{-1}$. Nevertheless, the weakened AMOC causes the SST to decrease about 10-30 years after the beginning of the Heinrich event as less warm waters from the Southern Hemisphere are transported into this region. However, it takes almost 300 years of iceberg discharge to transport the fresh melt water that far south to result in a decreasing SSS (Figure 9e). In ICE-300 the $\delta^{18} \mathrm{O}_{\text {seawater }}$ shows a slow decrease of about $1 \%$ over the length of the forcing, causing also a weak response in $\delta^{18} \mathrm{O}_{\text {calcite }}$. The steady supply of icebergs in ICE-600 and ICE-900 cause a much stronger decrease in SSS, $\delta^{18} \mathrm{O}_{\text {seawater }}$ and $\delta^{18} \mathrm{O}_{\text {calcite }}$ than in ICE-300, which indicates the importance of the length of the Heinrich event (Figure 9e).

Overall, we find two main patterns in $\delta^{18} \mathrm{O}_{\text {calcite }}$ in our model simulations. First, we find no or a delayed decrease in $\delta^{18} \mathrm{O}_{\text {calcite }}$ in the central and northeast North Atlantic regions, where the changes in SST and $\delta^{18} \mathrm{O}_{\text {seawater }}$ compensate each other. Second, the $\delta^{18} \mathrm{O}_{\text {calcite }}$ pattern closely follows that of $\delta^{18} \mathrm{O}_{\text {seawater }}$ in Baffin Bay, the Nordic Seas and the subtropical North Atlantic, where the change in $\delta^{18} \mathrm{O}_{\text {seawater }}$ exceeds the SST signal, and displays a continuous decrease over the length of the Heinrich event with the minimum value at the end of the iceberg release.

\section{Discussion}

\subsection{Can we use the modeled $\delta^{18} \mathrm{O}_{\text {calcite }}$ evolution to better understand the} $\delta^{18} \mathrm{O}_{\text {calcite }}$ recorded in marine sediment cores?

We compared our model results to planktonic $\delta^{18} \mathrm{O}_{\text {calcite }}$ data from four marine sediment cores distributed over a wide spatial area of the North Atlantic and Greenland - Iceland - Norwegian (GIN) Seas (Figure 8). These cores were selected because of the high temporal resolution of their planktonic $\delta^{18} \mathrm{O}$ records (time step of sim 200 years on average) and very good dating control. Two cores (NA87-22, CH69-K09) are situated within the Ruddiman Belt, one core (ENAM93-21) is located in the Norwegian Sea and the fourth core (KNR31 GPC-5) is relatively far south of Greenland 
Clim. Past Discuss., doi:10.5194/cp-2016-31, 2016

Manuscript under review for journal Clim. Past

Published: 17 March 2016

(c) Author(s) 2016. CC-BY 3.0 License.

(33 ${ }^{\circ}$ N, Figure 8). For cores NA87-22 and CH69-K09 $\delta^{18} \mathrm{O}_{\text {calcite }}$ was measured on two species: $G$. bulloides and N. pachyderma s. N. pachyderma s. is expected to prefer a deeper living habitat than $G$. bulloides and depending on the stratification of the water column the two species display a uniform (well mixed) or non-uniform pattern (stratified water column; Kohfeld et al. (1996); Simstich et al. (2003)). SST reconstructions derived from planktonic foraminifer counts and IRD data of these two cores (NA87-22, CH89-K09) are also displayed for comparison with simulated SSTs and IMF. The IRD data of core ENAM93-21 is also displayed (Figure 10).

Before looking in detail at the four cores to investigate whether or not the simulated patterns can be confirmed by the data, we have to point out that first, the sea level rise due to the released icebergs during HS1 is accounted for. Yet, we do not simulate the background sea level rise starting at $19 \mathrm{ka}$ after the onset of the LGM (Lambeck and Chappell, 2001; Lambeck et al., 2014). Therefore, the changing sea level causes lighter $\delta^{18} \mathrm{O}_{\text {calcite }}$ values in the proxy data, but does not affect the simulated values. Second, in the model we investigate the impact of sea surface temperature and $\delta^{18} \mathrm{O}_{\text {seawater }}$ on $\delta^{18} \mathrm{O}_{\text {calcite }}$ only and ignore other factors that impact the foraminifera, such as seasonality and depth habitat, which influence the $\delta^{18} \mathrm{O}_{\text {calcite }}$ recorded in foraminifera. Third, since the oceanic model has a resolution of $3^{\circ} \times 3^{\circ}$ in longitude and latitude, it is unlikely that the modeled $\delta^{18} \mathrm{O}_{\text {calcite }}$ signal within one grid cell fits perfectly to the recorded $\delta^{18} \mathrm{O}_{\text {calcite }}$ at one specific site. Therefore, our aim is to compare the modeled patterns to data, rather than comparing the values precisely computed at the corresponding grid cell to data. Finally, it is important to note that the regions we selected to analyze the pattern of simulated $\delta^{18} \mathrm{O}_{\text {calcite }}$ were not chosen to comprise the marine sediment core sites, instead they are of two types: (i) areas where simulated changes in sea surface temperature (cNA, Figure 8) or $\delta^{18} \mathrm{O}_{\text {seawater }}(\mathrm{BB}, \mathrm{NS}$, Fig. 8) are maximum, and (ii) areas where neither the change in SST nor in $\delta^{18} \mathrm{O}_{\text {seawater }}$ dominates (stNA, neNA, Figure 8).

365 The IRD pattern from core NA87-22 (Figure 10a) indicates an immediate increase of icebergs at $17.5 \mathrm{ka}$, which is accompanied by a decrease in $\delta^{18} \mathrm{O}_{\text {calcite }}$. At core NA87-22 the $\delta^{18} \mathrm{O}_{\text {calcite }}$ obtained from G. bulloides decreases suddenly $(-2 \%$ ) with the arrival of icebergs and stays low throughout HS1, whereas the $\delta^{18} \mathrm{O}_{\text {calcite }}$ obtained from $N$. pachyderma s. displays a gradual decrease (-1\%o) until the end of HS1 (Figure 10a). This non-uniform response in G. bulloides and N. pachyderma s. could be due to the deeper living habitat of $N$. pachyderma s. in a stratified water column.

In core $\mathrm{CH} 69-\mathrm{K} 09$ both species display a strong decrease of $2 \%$ in $\delta^{18} \mathrm{O}_{\text {calcite }}$ with the arrival of icebergs at $16 \mathrm{ka}$ (Figure 10c). Moreover, the annual mean SST decreases by about $5^{\circ} \mathrm{C}$ at $17.5 \mathrm{ka}$ without affecting the $\delta^{18} \mathrm{O}_{\text {calcite }}$ (Figure 10c). The lack of response in the recorded $\delta^{18} \mathrm{O}_{\text {calcite }}$

could be explained by a coinciding decrease in $\delta^{18} \mathrm{O}_{\text {seawater }}$ resulting from the arrival of cold meltwater, noting that the lack of simultaneous increase in IRD indicates that this cold meltwater was not accompanied by melting icebergs. Another possibility is that the isotopic data reflects properties of the subsurface, since the habitat depth of G. bulloides and N. pachyderma s. is often the pycnocline, 
Clim. Past Discuss., doi:10.5194/cp-2016-31, 2016

Manuscript under review for journal Clim. Past

Published: 17 March 2016

(c) Author(s) 2016. CC-BY 3.0 License.

whereas the reconstructed SST is derived from statistical relations between planktonic foraminifera

abundances and Atlas SST, and thus corresponds to the surface conditions.

The modeled pattern in the Baffin Bay region (Figure 9b) resembles relatively well the pattern seen in G. bulloides in core NA87-22 and CH69-K09. The model displays an immediate decrease in $\delta^{18} \mathrm{O}_{\text {calcite }}$ with the intrusion of iceberg melt water. The ICE-300 experiment displays the same magnitude of change as seen in the data (2\%o). At NA87-22 both species experience lighter $\delta^{18} \mathrm{O}_{\text {calcite }}$ values at the end of HS1, as does the G. bulloides at CH69-K09 (Figure 10a,c). This is not seen in the ICE-300 model set up where the $\delta^{18} \mathrm{O}_{\text {calcite }}$ value recovers to its initial value at the end of the iceberg discharge. Yet, it is important to note that the rising sea level unrelated to HS1 impacts the proxy data and therefore causes the lighter values, but is not incorporated into the model simulations.

The $\delta^{18} \mathrm{O}_{\text {calcite }}$ signal obtained from $N$. pachyderma s. in core ENAM93-21 displays a gradual decrease of $2.5 \%$ (Figure 10b). The IRD values decrease and then stabilize over the HS1 (Fig. 10b). This could be due to the cold conditions at the core location, which prevent the icebergs from melting. Also $i$ LOVECLIM displays low IMF values in the Nordic Seas region (Fig. 9c) and the modelled pattern of $\delta^{18} \mathrm{O}_{\text {calcite }}$ resembles the $\delta^{18} \mathrm{O}_{\text {calcite }}$ as recorded by N. pachyderma s. in ENAM93-21 (Figure 9c, Figure 10b). ICE-600 and ICE-900 display a decrease of $\operatorname{sim} 2.5 \%$, which fits to the proxy data, but it is important to note that the reconstructed SST in North Atlantic cores show an increase in SST at the end of the iceberg discharge, which is only seen in ICE-300.

In core KNR31-GPC5 G. ruber $\delta^{18} \mathrm{O}_{\text {calcite }}$ displays a short-lived increase of about $0.5 \%$ ojust at the beginning of HS1 and then a decrease of $1.5 \%$ ofollowed by another increase of $\operatorname{sim} 0.7 \%$. This pattern and magnitude is simulated in all experiments in the Central North Atlantic region (Figure 9a).

Overall, we see some similarities between the simulated and measured $\delta^{18} \mathrm{O}_{\text {calcite }}$ curves and we find that the set-up of an iceberg forcing of $0.2 \mathrm{~Sv}$ over 300 years yields the most reasonable results compared to the proxy data considered. It would be interesting to extend this investigation to more ocean cores, preferably also at sites closer to the calving locations. This modelling approach offers the possibility to analyze the timing of the Heinrich events at the different locations, its dependence on the evolution of sea surface temperatures and $\delta^{18} \mathrm{O}_{\text {seawater }}$. Moreover, it would be of great value to extend this research to other Heinrich events and to investigate if the patterns observed for HS1 are the same for all the Heinrich events, or if they vary and how they depend on the calving locations (e.g.

410 Laurentide Ice Sheet, Fennoscandian Ice Sheet or Barents Ice Sheet). Even though the model used has been proven to simulate the observed $\delta^{18} \mathrm{O}_{\text {calcite }}$ pattern satisfyingly at different time periods (Caley and Roche, 2013; Roche et al., 2014), as well as the iceberg distribution under pre-industrial conditions (Jongma et al., 2009; Bügelmayer et al., 2015a), the coarse resolution of our ocean and atmospheric model components and corresponding parameterizations might influence the simulated 
Clim. Past Discuss., doi:10.5194/cp-2016-31, 2016

Manuscript under review for journal Clim. Past

Published: 17 March 2016

(c) Author(s) 2016. CC-BY 3.0 License.

$\delta^{18} \mathrm{O}_{\text {calcite }}$ evolution. Therefore, it would be interesting to repeat this study with a higher resolved global climate model.

\subsection{General discussion}

The isotope-enabled climate model $i$ LOVECLIM offers the possibility to analyze the impact of icebergs on climate and their isotopic fingerprint during Heinrich events. Roche et al. (2014) found the best agreement between the simulated and measured calcite $\delta^{18} \mathrm{O}$ when applying a freshwater flux of $0.2 \mathrm{~Sv}$, which severely disturbs the AMOC. In our study we see that in $i$ LOVECLIM the AMOC's recovery time is not linearly related to the applied duration of the freshwater flux and it takes up to 2,200 years for the set-up with the longest forcing to recover. Otto-Bliesner and Brady (2010) concluded that in their climate model (CCSM3) the recovery of the AMOC under LGM conditions depends on the intensity of the applied freshwater forcing ( $0.1 \mathrm{~Sv}$ to $1 \mathrm{~Sv})$ and needs up to 500 years if strongly perturbed. This shows that the $i$ LOVECLIM model and the CCSM 3 do not have the same hysteresis shape in the AMOC-strength / amount of anomalous freshwater phase space (Ganopolski and Rahmstorf, 2001; Kageyama et al., 2010). The $i$ LOVECLIM model can be interpreted as close to bistability since the recovery time is so large with a massive freshwater flux (see discussion and figure 2 in Kageyama et al. (2010), where the CCSM3 model is in a clear monostable regime. Also other studies investigated the impact of different amounts of freshwater added as well as of various locations on the AMOC under LGM (e.g. Roche et al., 2010; Otto-Bliesner and Brady, 2010) and other climate conditions (Swingedouw et al., 2009), but we are not aware of another study testing the impact of the duration of the forcing.

Comparing the AMOC response in the present study to the experiments of Roche et al. (2014) shows that it recovers faster and is slightly ( $\operatorname{sim} 1 \mathrm{~Sv}$ ) less perturbed if the $0.2 \mathrm{~Sv}$ are applied as icebergs rather than as direct freshwater flux (our ICE-300 set-up, their dark green line in Figure 2a). Also Levine and Bigg (2008); Green et al. (2011) and Jongma et al. (2013) showed a different response of the AMOC to icebergs relative to freshwater hosing. Green et al. (2011) found that the effect on the AMOC of icebergs was only half of that of freshwater fluxes although icebergs caused the AMOC to recover slower.

Overall, we find a strong impact of the iceberg discharge on the ocean's conditions, especially in the longer runs. The cooling of about $8^{\circ} \mathrm{C}$ that we simulate in the North Atlantic in response to the icebergs' release is of the same order of magnitude as the cooling simulated in other modeling studies summarized by Kageyama et al. (2010). However, our simulated surface cooling is much stronger than the results presented by Green et al. (2011) and Jongma et al. (2013) due to the stronger weakening of the AMOC in our experiments. Note that the magnitude of our simulated surface cooling is comparable to that of the reconstructed cooling over HS1 in core CH69-K09. It should be further noted that reconstructed glacial SST changes have to be interpreted with caution at higher latitudes 
Clim. Past Discuss., doi:10.5194/cp-2016-31, 2016

Manuscript under review for journal Clim. Past

Published: 17 March 2016

(c) Author(s) 2016. CC-BY 3.0 License.

because planktonic foraminifer assemblages become monospecific at very low temperatures so that for SST reconstruction statistical methods are used outside of their range of strict applicability.

\section{Conclusion}

We have used the global climate model $i$ LOVECLIM to investigate the impact of the duration of a Heinrich event-like iceberg forcing on the North Atlantic Ocean and to analyze the mechanisms behind the $\delta^{18} \mathrm{O}_{\text {calcite }}$ pattern simulated in the model.

We find that the duration of the iceberg discharge (300, 600 and 900 years) strongly impacts the AMOC's response to the iceberg forcing. If an iceberg forcing of $0.2 \mathrm{~Sv}$ is applied for 300 years, the AMOC starts to recover immediately after the end of the iceberg release and reaches its initial value after 150 years. When the iceberg flux of $0.2 \mathrm{~Sv}$ is applied for 600 or 900 years, the AMOC does not start to recover for 700 and 2,200 years, respectively, after the forcing stops. This shows that in $i$ LOVECLIM the AMOC's response and recovery time strongly depend on the duration of the Heinrich event.

In the three experiments performed, the locations of the maximum change in SST, $\delta^{18} \mathrm{O}_{\text {seawater }}$ and $\delta^{18} \mathrm{O}_{\text {calcite }}$ are very similar, but the amplitude of the maximum changes in the ocean conditions depends on the duration of the iceberg forcing. Concerning the simulated $\delta^{18} \mathrm{O}_{\text {calcite }}$ signal, we distinguish two main patterns. First, we find no or a delayed decrease in $\delta^{18} \mathrm{O}_{\text {calcite }}$ in the central and northeast North Atlantic regions, where the changes in SST and $\delta^{18} \mathrm{O}_{\text {seawater }}$ compensate each other. Second, the $\delta^{18} \mathrm{O}_{\text {calcite }}$ pattern closely follows that of $\delta^{18} \mathrm{O}_{\text {seawater }}$ in Baffin Bay, the Nordic Seas and the subtropical North Atlantic, where the change in $\delta^{18} \mathrm{O}_{\text {seawater }}$ exceeds the SST signal, 470 and displays a continuous decrease over the length of the Heinrich event with the minimum value at the end of the iceberg release. Moreover, the effect of the iceberg release on regions located far away from the calving sites strongly depends on the length of the iceberg release. Yet, our results show that the timing of the first response to the iceberg forcing in SST, $\delta^{18} \mathrm{O}_{\text {seawater }}$ and $\delta^{18} \mathrm{O}_{\text {calcite }}$ coincides between all the experiments in the various regions within 300 years.

475 From the comparison of simulated sea surface temperatures and $\delta^{18} \mathrm{O}_{\text {calcite }}$ with proxy data, we find the best agreement between model output and data is reached when the iceberg discharge is stopped after 300 years. This is in agreement with the earlier findings of Roche et al. (2004, 2014) and Roberts et al. (2014).

Acknowledgements. This work is a contribution to the NWO/VIDI "AC2ME" project ( $\left.{ }^{\circ} 864.09 .013\right)$ and to the ACCLIMATE ERC project funded by the European Research Council under the European Union's Seventh Framework Programme (FP7/2007-2013)/ERC grant agreement no 339108. M. Bügelmayer-Blaschek is supported by NWO under project number $n^{\circ} 864.09 .013$, D.M. Roche is supported by NWO under project number $n^{\circ} 864.09 .013$ and by CNRS-INSU, C. Waelbroeck by CNRS-INSU. The authors wish to thank Catherine Ritz for the use of the GRISLI ice sheet model. Institute Pierre Simon Laplace is acknowledged for hosting 
Clim. Past Discuss., doi:10.5194/cp-2016-31, 2016

Manuscript under review for journal Clim. Past

Published: 17 March 2016

(c) Author(s) 2016. CC-BY 3.0 License.

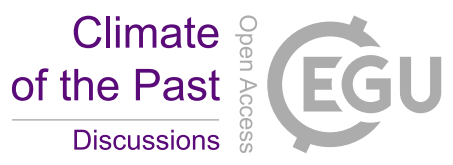

485 the iLOVECLIM model code under the- LUDUS framework project (https://forge.ipsl.jussieu.fr/ludus). This is NWO/AC2ME contribution number 11. 
Clim. Past Discuss., doi:10.5194/cp-2016-31, 2016

Manuscript under review for journal Clim. Past

Published: 17 March 2016

(c) Author(s) 2016. CC-BY 3.0 License.

\section{References}

Andrews, J. T. et al.: Icebergs and iceberg rafted detritus (IRD) in the North Atlantic: facts and assumptions, OCEANOGRAPHY-WASHINGTON DC-OCEANOGRAPHY SOCIETY-, 13, 100-108, 2000.

Balcerak, E.: Protactinium-thorium ratio as a proxy for ocean circulation, Eos, Transactions American Geophysical Union, 92, 488-488, doi:10.1029/2011EO510014, 2011.

Bigg, G. R., Wadley, M. R., Stevens, D. P., and Johnson, J. A.: Prediction of iceberg trajectories for the North Atlantic and Arctic Oceans, Geophysical research letters, 23, 3587-3590, doi:10.1029/96GL03369, 1996.

Bigg, G. R., Wadley, M. R., Stevens, D. P., and Johnson, J. A.: Modelling the dynamics and thermodynamics of icebergs, Cold Regions Science and Technology, 26, 113-135, doi:10.1016/S0165-232X00012-8, 1997.

Broecker, W. S., Peteet, D. M., and Rind, D.: Does the ocean-atmosphere system have more than one stable mode of operation?, Nature, 315, 21-26, doi:10.1038/315021a0, 1985.

Brovkin, V., Ganopolski, A., and Svirezhev, Y.: A continuous climate-vegetation classification for use in climate-biosphere studies, Ecological Modelling, 101, 251-261, doi:10.1016/S0304-3800(97)00049-5, 1997.

Bügelmayer, M., Roche, D., and Renssen, H.: How do icebergs affect the Greenland ice sheet under preindustrial conditions?-a model study with a fully coupled ice-sheet-climate model, The Cryosphere, 9, 821835, doi:10.5194/tc-9-821-2015, 2015a.

Bügelmayer, M., Roche, D., and Renssen, H.: Representing icebergs in the iLOVECLIM model (version 1.0)-a sensitivity study, Geoscientific Model Development, 8, 2139-2151, 2015b.

Caley, T. and Roche, D.: $\delta 18$ O water isotope in the iLOVECLIM model (version 1.0)-Part 3: A palaeoperspective based on present-day data-model comparison for oxygen stable isotopes in carbonates, Geoscientific Model Development, 6, 1505-1516, 2013.

Campin, J.-M. and Goosse, H.: Parameterization of density-driven downsloping flow for a coarse-resolution ocean model in z-coordinate, Tellus A, 51, 412-430, 1999.

Deleersnijder, E. and Campin, J.-M.: On the computation of the barotropic mode of a free-surface world, Ann. Geophysicae, 13, 675-688, 1995.

Deleersnijder, E., Beckers, J.-M., Campin, J.-M., El Mohajir, M., Fichefet, T., and Luyten, P.: Some mathematical problems associated with the development and use of marine models, Springer, 1997.

515 Dokken, T. M. and Jansen, E.: Rapid changes in the mechanism of ocean convection during the last glacial period, Nature, 401, 458-461, 1999.

Dowdeswell, J. A., Whittington, R. J., and Hodgkins, R.: The sizes, frequencies, and freeboards of East Greenland icebergs observed using ship radar and sextant, Journal of Geophysical Research: Oceans (1978-2012), 97, 3515-3528, doi:10.1029/91JC02821, 1992.

Elliot, M., Labeyrie, L., and Duplessy, J.-C.: Changes in North Atlantic deep-water formation associated with the Dansgaard-Oeschger temperature oscillations (60-10ka), Quaternary Science Reviews, 21, 1153-1165, 2002.

Fichefet, T. and Maqueda, M. M.: Sensitivity of a global sea ice model to the treatment of ice thermodynamics and dynamics, Journal of Geophysical Research: Oceans (1978-2012), 102, 12609-12 646, doi:10.1029/97JC00480, 1997. 
Clim. Past Discuss., doi:10.5194/cp-2016-31, 2016

Manuscript under review for journal Clim. Past

Published: 17 March 2016

(c) Author(s) 2016. CC-BY 3.0 License.

Fichefet, T. and Maqueda, M. M.: Modelling the influence of snow accumulation and snow-ice formation on the seasonal cycle of the Antarctic sea-ice cover, Climate Dynamics, 15, 251-268, doi:10.1007/s003820050280, 1999.

Ganopolski, A. and Rahmstorf, S.: Rapid changes of glacial climate simulated in a coupled climate model, Nature, 409, 153-158, doi:40f9.6817:153-158, 2001.

Geibert, W. and Usbeck, R.: Adsorption of thorium and protactinium onto different particle types: experimental findings, Geochimica et Cosmochimica Acta, 68, 1489-1501, doi:10.1016/j.gca.2003.10.011, 2004.

Gherardi, J.-M., Labeyrie, L., McManus, J., Francois, R., Skinner, L., and Cortijo, E.: Evidence from the Northeastern Atlantic basin for variability in the rate of the meridional overturning circulation through the last deglaciation, Earth and Planetary Science Letters, 240, 710-723, doi:10.1016/j.epsl.2005.09.061, 2005.

Gherardi, J.-M., Labeyrie, L., Nave, S., Francois, R., McManus, J. F., and Cortijo, E.: Glacial-interglacial circulation changes inferred from 231Pa/230Th sedimentary record in the North Atlantic region, Paleoceanography, 24, doi:10.1029/2008PA001696, 2009.

Gladstone, R. M., Bigg, G. R., and Nicholls, K. W.: Iceberg trajectory modeling and meltwater injection in the 540 Southern Ocean, Journal of Geophysical Research: Oceans (1978-2012), 106, 19 903-19 915, 2001.

Goosse, H., Brovkin, V., Fichefet, T., Haarsma, R., Huybrechts, P., Jongma, J., Mouchet, A., Selten, F., Barriat, P.-Y., Campin, J.-M., et al.: Description of the Earth system model of intermediate complexity LOVECLIM version 1.2, Geoscientific Model Development, 3, 603-633, doi:10.5194/gmd-3-603-2010, 2010.

Green, C. L., Green, J., and Bigg, G. R.: Simulating the impact of freshwater inputs and deep-draft icebergs formed during a MIS 6 Barents Ice Sheet collapse, Paleoceanography, 26, doi:10.1029/2010PA002088, 2011.

Heinrich, H.: Origin and consequences of cyclic ice rafting in the northeast Atlantic Ocean during the past 130,000 years, Quaternary research, 29, 142-152, 1988.

Hemming, S. R.: Heinrich events: Massive late Pleistocene detritus layers of the North Atlantic and their global climate imprint, Reviews of Geophysics, 42, doi:10.1029/2003rg000128.1.Introduction, 2004.

550 Hewitt, C., Broccoli, A., Crucifix, M., Gregory, J., Mitchell, J., and Stouffer, R.: The effect of a large freshwater perturbation on the glacial North Atlantic Ocean using a coupled general circulation model, Journal of Climate, 19, 4436-4447, doi:10.1175/JCLI3867.1, 2006.

Hewitt, C. D., Broccoli, A. J., Mitchell, J. F., and Stouffer, R. J.: A coupled model study of the last glacial maximum: Was part of the North Atlantic relatively warm?, Geophysical Research Letters, 28, 1571-1574, 2001.

Jongma, J., Renssen, H., and Roche, D.: Simulating Heinrich event 1 with interactive icebergs, Climate Dynamics, 40, 1373-1385, doi:10.1007/s00382-012-1421-1, 2013.

Jongma, J. I., Driesschaert, E., Fichefet, T., Goosse, H., and Renssen, H.: The effect of dynamic-thermodynamic icebergs on the Southern Ocean climate in a three-dimensional model, Ocean Modelling, 26, 104-113, doi:10.1016/j.ocemod.2008.09.007, 2009.

Kageyama, M., Paul, A., Roche, D. M., and Van Meerbeeck, C. J.: Modelling glacial climatic millennial-scale variability related to changes in the Atlantic meridional overturning circulation: a review, Quaternary Science Reviews, 29, 2931-2956, doi:10.1016/j.quascirev.2010.05.029, 2010.

Keigwin, L., Jones, G., Lehman, S., and Boyle, E.: Deglacial meltwater discharge, North Atlantic deep circulation, and abrupt climate change, J. geophys. Res, 96, 811-16, 1991. 
Clim. Past Discuss., doi:10.5194/cp-2016-31, 2016

Manuscript under review for journal Clim. Past

Published: 17 March 2016

(c) Author(s) 2016. CC-BY 3.0 License.

Keigwin, L. D. and Boyle, E. A.: Surface and deep ocean variability in the northern Sargasso Sea during marine isotope stage 3, Paleoceanography, 14, 164-170, 1999.

Kohfeld, K. E., Fairbanks, R. G., Smith, S. L., and Walsh, I. D.: Neogloboquadrina pachyderma (sinistral coiling) as paleoceanographic tracers in polar oceans: Evidence from Northeast Water Polynya plankton tows, sediment traps, and surface sediments, Paleoceanography, 11, 679-699, doi:10.1029/96PA02617, 1996.

Labeyrie, L., Leclaire, H., Waelbroeck, C., Cortijo, E., Jean-Claude, D., Vidal, L., Elliot, M., Le Coat, B., and Auffret, G.: Temporal variability of the surface and deep waters of the North West Atlantic Ocean at orbital and millennial scales, Geophysical Monograph Series 112, Mechanisms of global climate change at millennial time scales, 112, 77-98, 1999.

Lambeck, K. and Chappell, J.: Sea level change through the last glacial cycle, Science, 292, 679-686, doi:10.1126/science.1059549, 2001.

Lambeck, K., Rouby, H., Purcell, A., Sun, Y., and Sambridge, M.: Sea level and global ice volumes from the Last Glacial Maximum to the Holocene, Proceedings of the National Academy of Sciences, 111, 15 29615303, doi:10.1073/pnas.1411762111, 2014.

Levine, R. C. and Bigg, G. R.: Sensitivity of the glacial ocean to Heinrich events from different iceberg sources, as modeled by a coupled atmosphere-iceberg-ocean model, Paleoceanography, 23, doi:10.1029/2008PA001613, 2008.

Løset, S.: Thermal energy conservation in icebergs and tracking by temperature, Journal of Geophysical Research: Oceans (1978-2012), 98, 10 001-10 012, 1993.

Lynch-Stieglitz, J., Stocker, T. F., Broecker, W. S., and Fairbanks, R. G.: The influence of air-sea exchange on the isotopic composition of oceanic carbon: Observations and modeling, Global Biogeochemical Cycles, 9, 653-665, 1995.

Manabe, S. and Stouffer, R. J.: Simulation of abrupt climate change induced by freshwater input to the North Atlantic Ocean, Nature, 378, 165-167, 1995.

McManus, J., Francois, R., Gherardi, J.-M., Keigwin, L., and Brown-Leger, S.: Collapse and rapid resumption of Atlantic meridional circulation linked to deglacial climate changes, Nature, 428, 834-837, doi:10.1038/nature02494, 2004.

Opsteegh, J., Haarsma, R., Selten, F., and Kattenberg, A.: ECBILT: A dynamic alternative to mixed boundary conditions in ocean models, Tellus A, 50, 1998.

Otto-Bliesner, B. L. and Brady, E. C.: The sensitivity of the climate response to the magnitude and location of freshwater forcing: last glacial maximum experiments, Quaternary Science Reviews, 29, 56-73, 2010.

Rahmstorf, S.: Ocean circulation and climate during the past 120,000 years, Nature, 419, 207-214, doi:10.1038/nature01090, 2002.

Rasmussen, T., Van Weering, T. C., and Labeyrie, L.: High resolution stratigraphy of the Faeroe-Shetland channel and its relation to North Atlantic paleoceanography: The last 87 kyr, Marine Geology, 131, 75-88, doi:10.1016/0025-3227(95)00145-X, 1996a.

Rasmussen, T. L., Thomsen, E., Weering, T. C., and Labeyrie, L.: Rapid changes in surface and deep water conditions at the Faeroe Margin during the last 58,000 years, Paleoceanography, 11, 757-771, doi:10.1029/96PA02618, 1996b. 
Clim. Past Discuss., doi:10.5194/cp-2016-31, 2016

Manuscript under review for journal Clim. Past

Published: 17 March 2016

(c) Author(s) 2016. CC-BY 3.0 License.

Rasmussen, T. L., Thomsen, E., and Van Weering, T. C.: Cyclic sedimentation on the Faeroe Drift 53-10 ka BP related to climatic variations, Geological Society, London, Special Publications, 129, 255-267, doi:10.1144/GSL.SP.1998.129.01.16, 1998.

Rignot, E., Velicogna, I., Van den Broeke, M., Monaghan, A., and Lenaerts, J.: Acceleration of the contribution of the Greenland and Antarctic ice sheets to sea level rise, Geophysical Research Letters, 38, doi:10.1029/2011GL046583, 2011.

Roberts, W. H., Valdes, P. J., and Payne, A. J.: A new constraint on the size of Heinrich Events from an iceberg/sediment model, Earth and Planetary Science Letters, 386, 1-9, doi:10.1016/j.epsl.2013.10.020, 2014.

Roche, D.: $\delta 18 \mathrm{O}$ water isotope in the iLOVECLIM model (version 1.0)-Part 1: Implementation and verification, Geoscientific Model Development, 6, 1481-1491, doi:10.5194/gmd-6-1481-2013, 2013.

615 Roche, D., Paillard, D., and Cortijo, E.: Constraints on the duration and freshwater release of Heinrich event 4 through isotope modelling, Nature, 432, 379-382, doi:10.1038/nature03059, 2004.

Roche, D. M. and Paillard, D.: Modelling the oxygen-18 and rapid glacial climatic events: a data-model comparison, Comptes Rendus Geoscience, 337, 928-934, doi:10.1016/j.crte.2005.03.019, 2005.

Roche, D. M., Wiersma, A. P., and Renssen, H.: A systematic study of the impact of freshwater pulses with respect to different geographical locations, Climate Dynamics, 34, 997-1013, 2010.

Roche, D. M., Paillard, D., Caley, T., and Waelbroeck, C.: LGM hosing approach to Heinrich Event 1: results and perspectives from data-model integration using water isotopes, Quaternary Science Reviews, 106, 247 261, doi:10.1016/j.quascirev.2014.07.020, 2014.

Rossow, W. B., Walker, A. W., Beuschel, D. E., and Roiter, M. D.: International satellite cloud climatology project (ISCCP) documentation of new cloud datasets, vol. WMO/TD-No 737, World Meteorological Organisation, 1996.

Ruddiman, W. F.: Late Quaternary deposition of ice-rafted sand in the subpolar North Atlantic (lat 40 to $65 \mathrm{~N}$ ), Geological Society of America Bulletin, 88, 1813-1827, doi:10.1130/0016-7606(1977)88, 1977.

Schmittner, A., Yoshimori, M., and Weaver, A. J.: Instability of glacial climate in a model of the oceanatmosphere-cryosphere system, Science, 295, 1489-1493, doi:10.1126/science.1066174, 2002.

Seidov, D. and Maslin, M.: North Atlantic deep water circulation collapse during Heinrich events, Geology, 27, 23-26, 1999.

Shackleton, N.: Attainment of isotopic equilibrium between ocean water and the benthonic foraminifera genus Uvigerina: isotopic changes in the ocean during the last glacial, 1974.

Shackleton, N. J., Hall, M. A., and Vincent, E.: Phase relationships between millennial-scale events 64,00024,000 years ago, Paleoceanography, 15, 565-569, doi:10.1029/2000PA000513, 2000.

Simstich, J., Sarnthein, M., and Erlenkeuser, H.: Paired $\delta 18$ O signals of Neogloboquadrina pachyderma (s) and Turborotalita quinqueloba show thermal stratification structure in Nordic Seas, Marine Micropaleontology, 48, 107-125, doi:10.1016/S0377-8398(02)00165-2, 2003.

640 Smith, R. S. and Gregory, J. M.: A study of the sensitivity of ocean overturning circulation and climate to freshwater input in different regions of the North Atlantic, Geophysical Research Letters, 36, doi:10.1029/2009GL038607, 2009.

Smith, S. D.: Hindcasting iceberg drift using current profiles and winds, Cold regions science and technology, 22, 33-45, doi:10.1016/0165-232X(93)90044-9, 1993. 
Clim. Past Discuss., doi:10.5194/cp-2016-31, 2016

Manuscript under review for journal Clim. Past

Published: 17 March 2016

(c) Author(s) 2016. CC-BY 3.0 License.

Smith, S. D. and Banke, E. G.: The influence of winds, currents and towing forces on the drift of icebergs, Cold Regions Science and Technology, 6, 241-255, 1983.

Stommel, H.: Thermohaline convection with two stable regimes of flow, Tellus A, 13, doi:10.3402/tellusa.v13i2.9491, 1961.

Stouffer, R. J., Yin, J., Gregory, J., Dixon, K., Spelman, M., Hurlin, W., Weaver, A., Eby, M., Flato, G., Hasumi,

H., et al.: Investigating the causes of the response of the thermohaline circulation to past and future climate changes, Journal of Climate, 19, 1365-1387, doi:10.1175/JCLI3689.1, 2006.

Swingedouw, D., Fichefet, T., Goosse, H., and Loutre, M.-F.: Impact of transient freshwater releases in the Southern Ocean on the AMOC and climate, Climate dynamics, 33, 365-381, doi:10.1175/2009JCLI3028.1, 2009.

Timmermann, A., Krebs, U., Justino, F., Goosse, H., and Ivanochko, T.: Mechanisms for millennial-scale global synchronization during the last glacial period, Paleoceanography, 20, doi:10.1029/2004PA001090, 2005.

Urey, H. C.: The thermodynamic properties of isotopic substances, Journal of the Chemical Society (Resumed), pp. 562-581, doi:10.1039/JR9470000562, 1947.

Vidal, L., Labeyrie, L., Cortijo, E., Arnold, M., Duplessy, J., Michel, E., Becque, S., and Van Weering, T.: Evidence for changes in the North Atlantic Deep Water linked to meltwater surges during the Heinrich events, Earth and Planetary Science Letters, 146, 13-27, doi:10.1016/S0012-821X(96)00192-6, 1997.

Vizcaíno, M., Mikolajewicz, U., Gröger, M., Maier-Reimer, E., Schurgers, G., and Winguth, A. M.: Longterm ice sheet-climate interactions under anthropogenic greenhouse forcing simulated with a complex Earth System Model, Climate dynamics, 31, 665-690, doi:10.1007/s00382-008-0369-7, 2008.

665 Waelbroeck, C., Labeyrie, L., Duplessy, J.-C., Guiot, J., Labracherie, M., Leclaire, H., and Duprat, J.: Improving past sea surface temperature estimates based on planktonic fossil faunas, Paleoceanography, 13, 272-283, 1998.

Waelbroeck, C., Duplessy, J.-C., Michel, E., Labeyrie, L., Paillard, D., and Duprat, J.: The timing of the last deglaciation in North Atlantic climate records, Nature, 412, 724-727, doi:10.1038/35089060, 2001.

670 Waelbroeck, C., Levi, C., Duplessy, J., Labeyrie, L., Michel, E., Cortijo, E., Bassinot, F., and Guichard, F.: Distant origin of circulation changes in the Indian Ocean during the last deglaciation, Earth and Planetary Science Letters, 243, 244-251, doi:10.1016/j.epsl.2005.12.031, 2006.

Waelbroeck, C., Skinner, L., Labeyrie, L., Duplessy, J.-C., Michel, E., Vazquez Riveiros, N., Gherardi, J.M., and Dewilde, F.: The timing of deglacial circulation changes in the Atlantic, Paleoceanography, 26, doi:10.1029/2010PA002007, 2011.

Wiersma, A. P. and Jongma, J. I.: A role for icebergs in the 8.2 ka climate event, Climate dynamics, 35, 535-549, doi:10.1007/s00382-009-0645-1, 2010.

Yu, E.-F., Francois, R., and Bacon, M. P.: Similar rates of modern and last-glacial ocean thermohaline circulation inferred, Nature, 379, 689-694, doi:10.1038/379689a0, 1996. 
Clim. Past Discuss., doi:10.5194/cp-2016-31, 2016

Manuscript under review for journal Clim. Past

Published: 17 March 2016

(c) Author(s) 2016. CC-BY 3.0 License.
Climate
of the Past
Discussions

\section{(c) (i)}

CALVING SITES

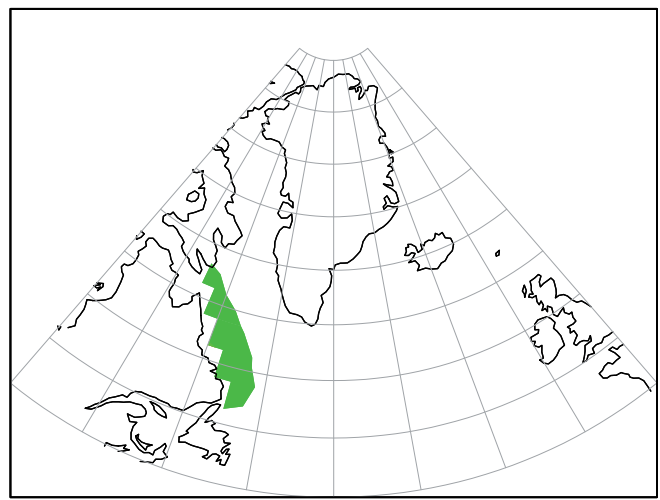

Figure 1. Calving location

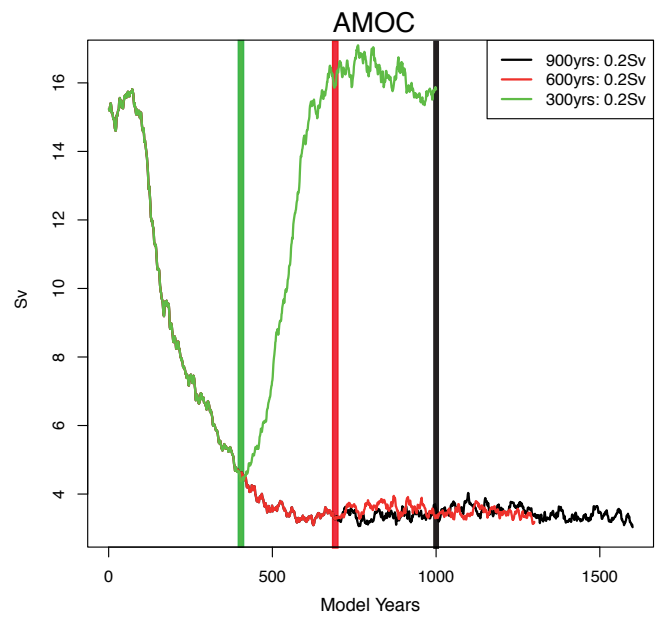

Figure 2. Time evolution of the Atlantic Meridional Overturning Circulation (AMOC) as simulated in ICE300, ICE-600 and ICE-900, the color bars (green, red, black) denote the end of the freshwater forcing of the respective runs 
Clim. Past Discuss., doi:10.5194/cp-2016-31, 2016

Manuscript under review for journal Clim. Past

Published: 17 March 2016

(c) Author(s) 2016. CC-BY 3.0 License.

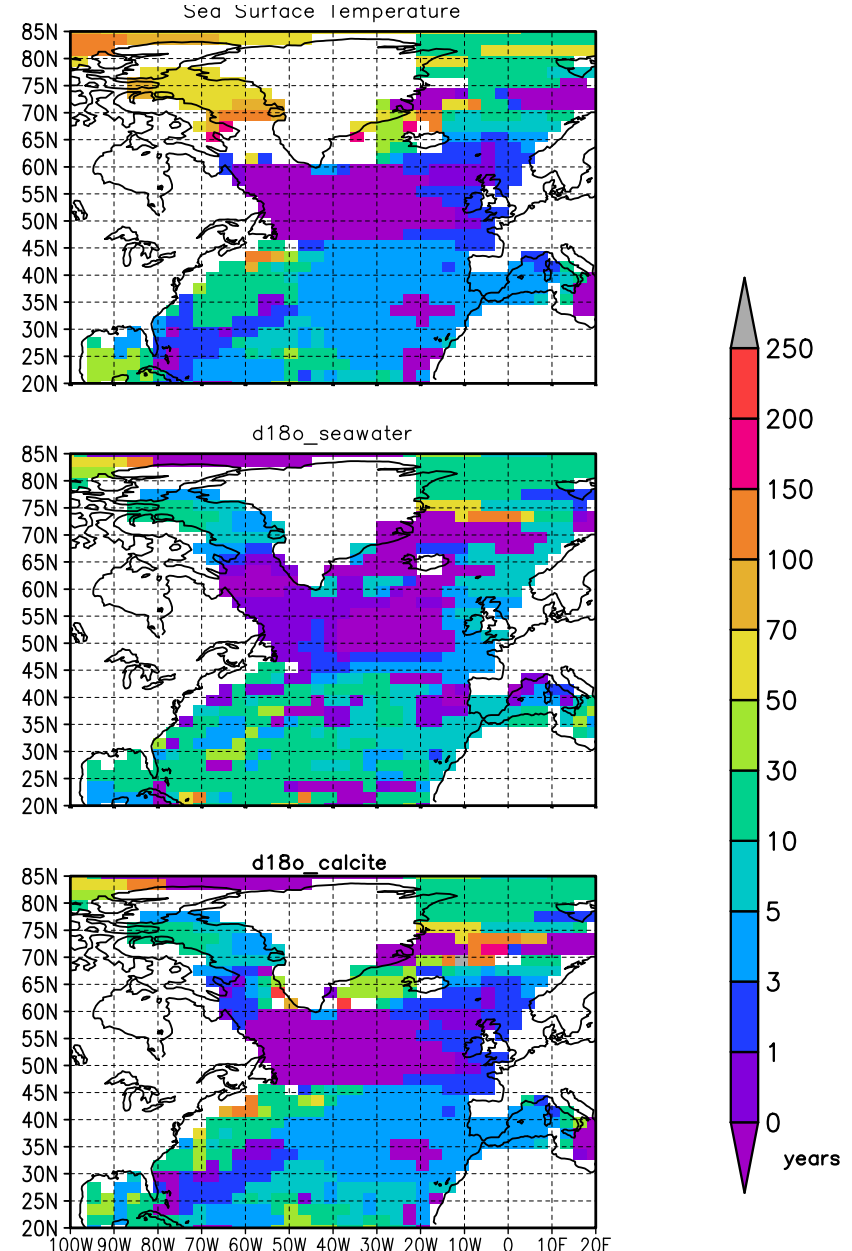

Figure 3. Timing of the first significant change (5\%) in (a): Sea Surface Temperature (SST); (b): $\delta^{18} \mathrm{O}_{\text {seawater }}$; (c): $\delta^{18} \mathrm{O}_{\text {calcite }}$; white areas do not display significant changes 
Clim. Past Discuss., doi:10.5194/cp-2016-31, 2016

Manuscript under review for journal Clim. Past

Published: 17 March 2016

(c) Author(s) 2016. CC-BY 3.0 License.

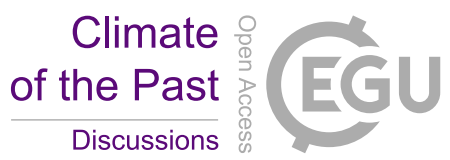

(c) (i)

LGM - control state

a)

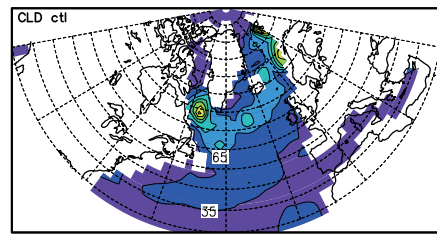

c)

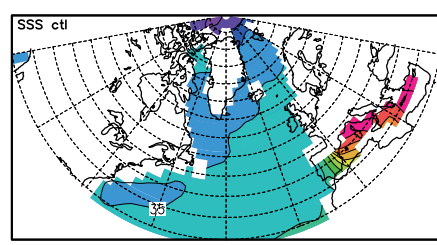

e)

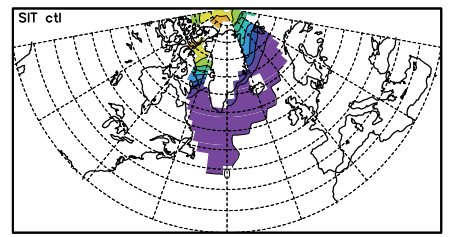

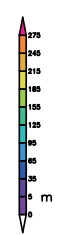
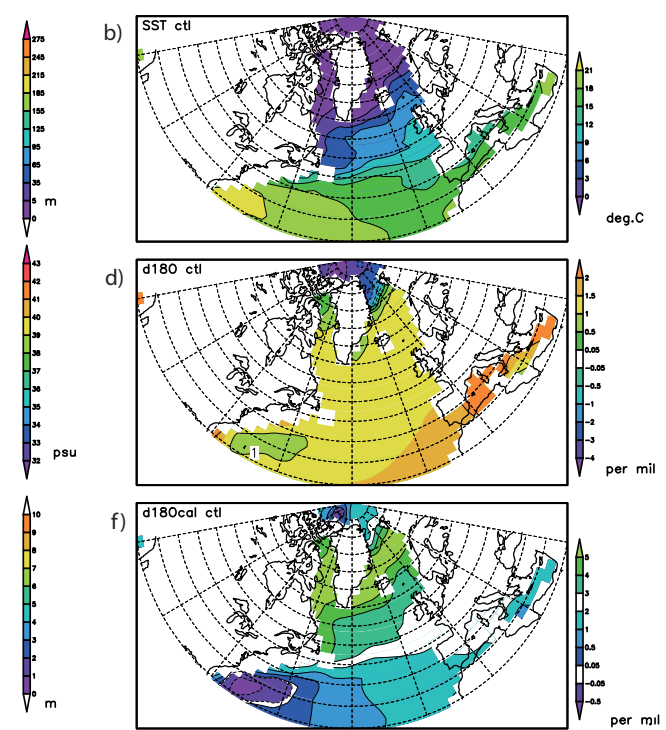

Figure 4. mean 100 year LGM control state; (a) Convection Layer Depth (CLD, m); (b) Sea Surface Temperature (SST, ${ }^{\circ}$ C); (c) Sea Surface Salinity (SSS, psu); (d) $\delta^{18} \mathrm{O}_{\text {seawater }}(\%)$; (e) Sea Ice Thickness (SIT, m); (f) $\delta^{18} \mathrm{O}_{\text {calcite }},(\%)$ 
Clim. Past Discuss., doi:10.5194/cp-2016-31, 2016

Manuscript under review for journal Clim. Past

Published: 17 March 2016

(c) Author(s) 2016. CC-BY 3.0 License.
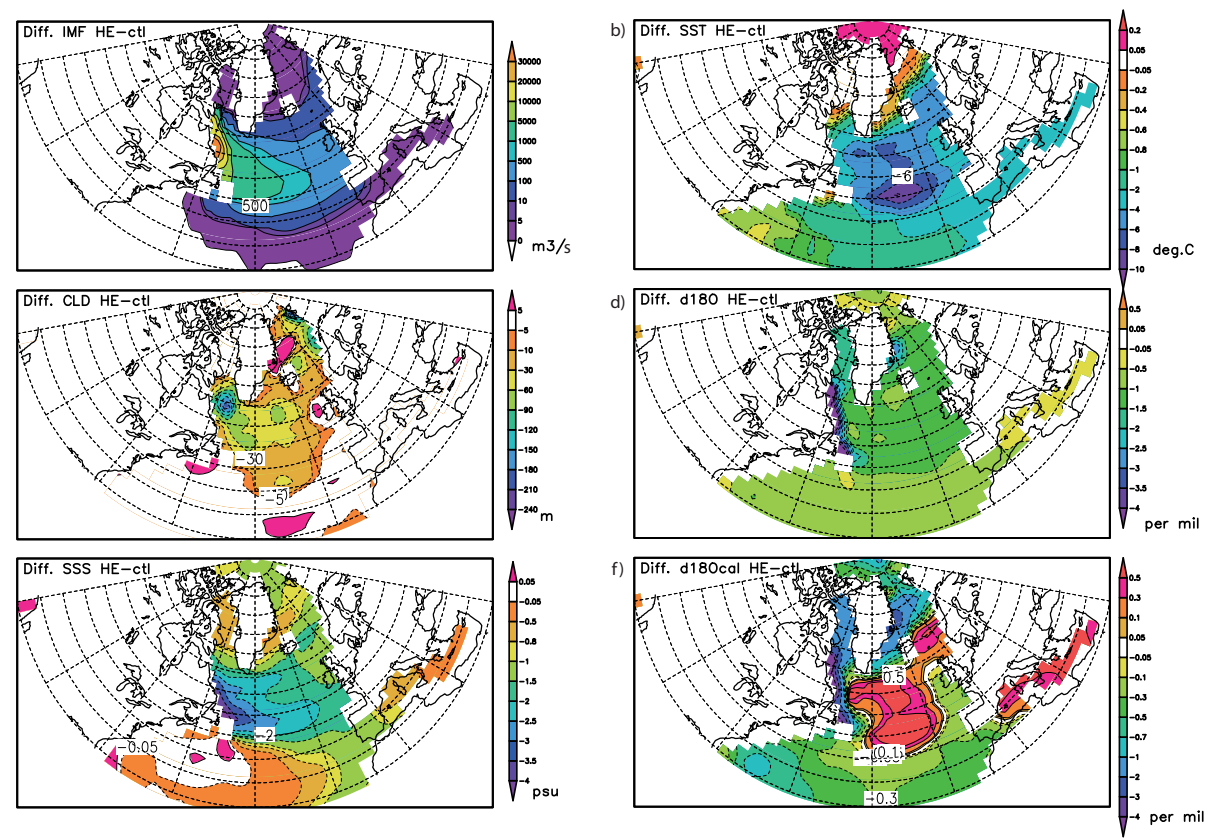

Figure 5. Difference between annual mean values of perturbed state and reference state as simulated in ICE300. The perturbed state corresponds to the last 100 years of the freshwater forcing and the reference state corresponds to the first 100 years of the experiments (no freshwater forcing applied yet). (a)Iceberg Melt Flux (IMF, $\mathrm{m}^{3} \mathrm{~s}^{-1}$ ); (b) Sea Surface Temperature (SST, ${ }^{\circ} \mathrm{C}$ ); (c) Convection Layer Depth (CLD, m); (d) $\delta^{18} \mathrm{O}_{\text {seawater }}\left(\%\right.$ ) ; (e) Sea Surface Salinity (SSS, psu); (f) $\delta^{18} \mathrm{O}_{\text {calcite }},(\% o)$ 
Clim. Past Discuss., doi:10.5194/cp-2016-31, 2016

Manuscript under review for journal Clim. Past

Published: 17 March 2016

(c) Author(s) 2016. CC-BY 3.0 License.

\section{Climate of the Past \\ Discussions}

(c) (1)

ICE - 600
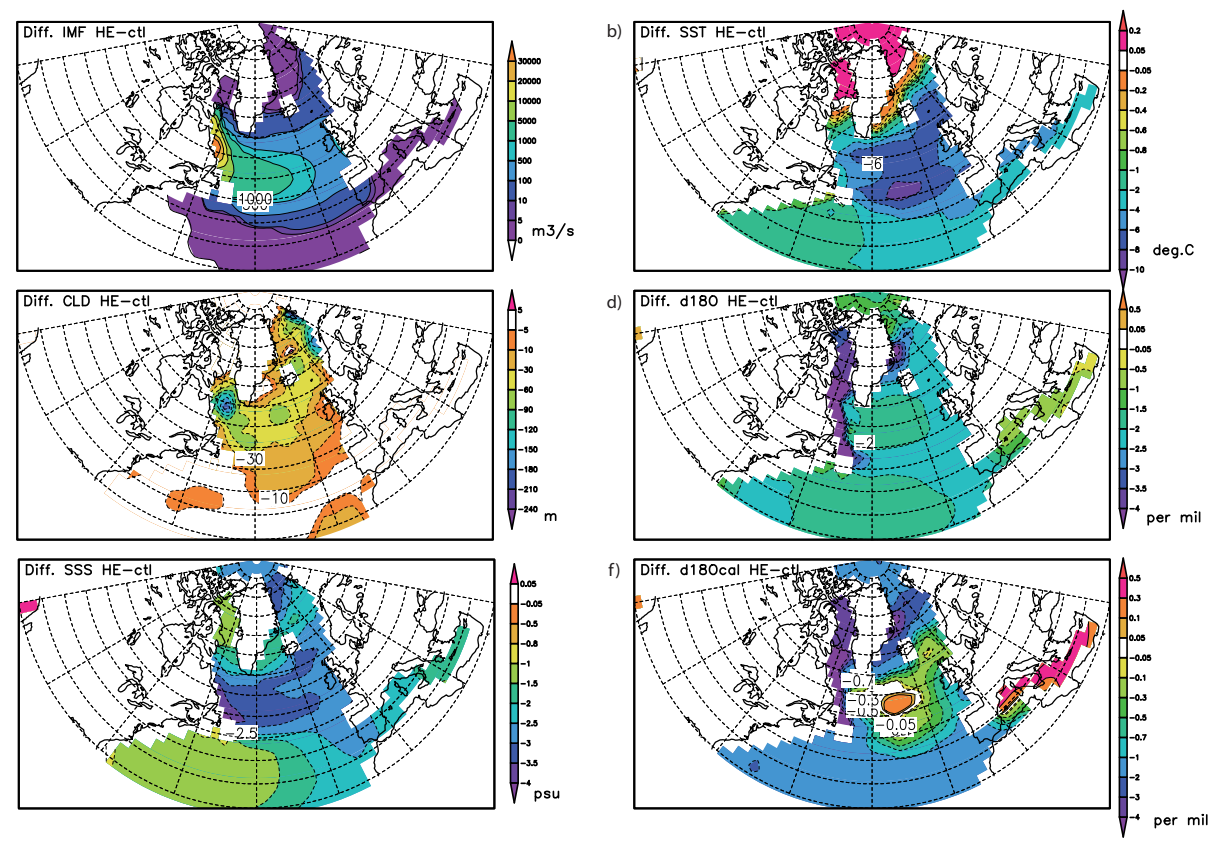

Figure 6. same as Figure 5, but for ICE-600 
Clim. Past Discuss., doi:10.5194/cp-2016-31, 2016

Manuscript under review for journal Clim. Past

Published: 17 March 2016

(c) Author(s) 2016. CC-BY 3.0 License.

\section{Climate of the Past \\ Discussions}

(c) (1)

ICE - 900
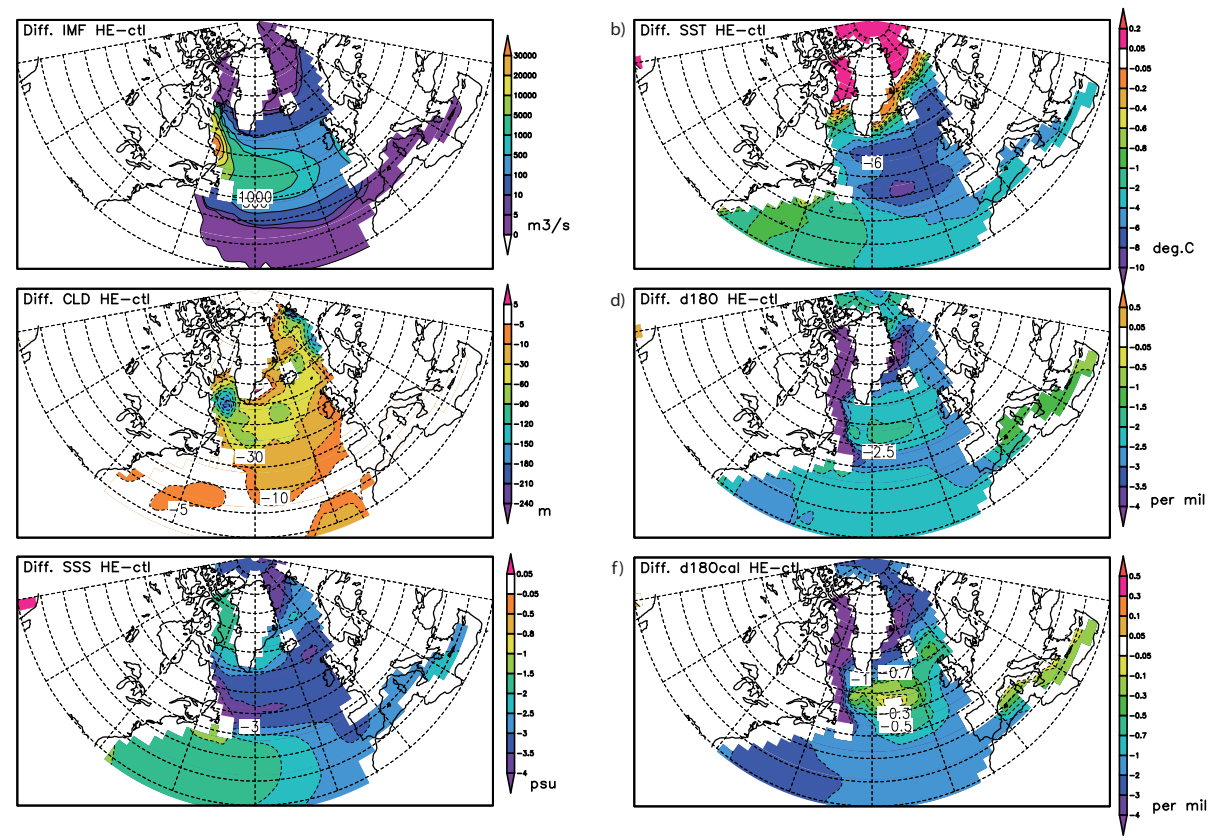

Figure 7. same as Figure 5, but for ICE-900 
Clim. Past Discuss., doi:10.5194/cp-2016-31, 2016

Manuscript under review for journal Clim. Past

Published: 17 March 2016

(c) Author(s) 2016. CC-BY 3.0 License.

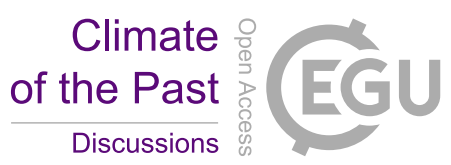

(c) (i)

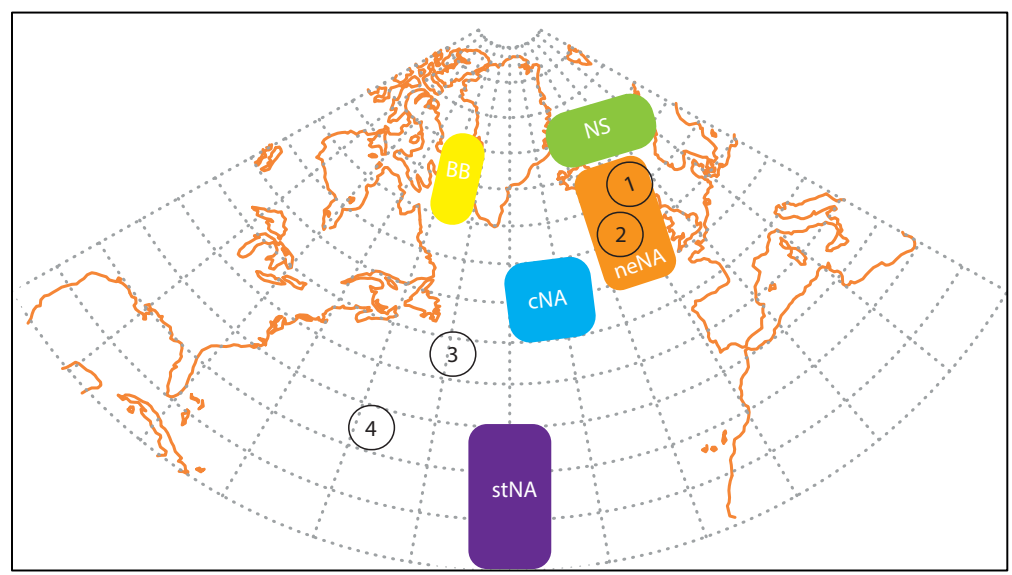

Figure 8. Map with areas that are used to compute the area-averaged time series in Figure 9; Central North Atlantic (cNA): $40-25^{\circ} \mathrm{W}, 45-55^{\circ} \mathrm{N}$; Baffin Bay (BB): $60-45^{\circ} \mathrm{W}, 60-70^{\circ} \mathrm{N}$; c) Nordic Seas (NS): $20^{\circ} \mathrm{W}-$ $20^{\circ} \mathrm{E}, 65-75^{\circ} \mathrm{N}$; Northeast North Atlantic (neNA): $20^{\circ} \mathrm{W}-0^{\circ} \mathrm{E}, 50-65^{\circ} \mathrm{N}$; subtropical North Atlantic (stNA): $45-35^{\circ} \mathrm{W}, 20-35^{\circ} \mathrm{N}$; numbers correspond to marine sediment cores presented in Figure 10: (1) ENAM93$21\left(62,7^{\circ} \mathrm{N}, 4^{\circ} \mathrm{W}\right) ;(2) \mathrm{NA} 87-22\left(55.5^{\circ} \mathrm{N} ; 14.7^{\circ} \mathrm{W}\right) ;(3) \mathrm{CH} 69-\mathrm{K} 09\left(41.8^{\circ} \mathrm{N}, 47.4^{\circ} \mathrm{W}\right) ;(4) \mathrm{KNR} 31 \mathrm{GPC}-5$ $\left(33.7^{\circ} \mathrm{N}, 57.6^{\circ} \mathrm{W}\right)$ 
Clim. Past Discuss., doi:10.5194/cp-2016-31, 2016

Manuscript under review for journal Clim. Past

Published: 17 March 2016

(c) Author(s) 2016. CC-BY 3.0 License.
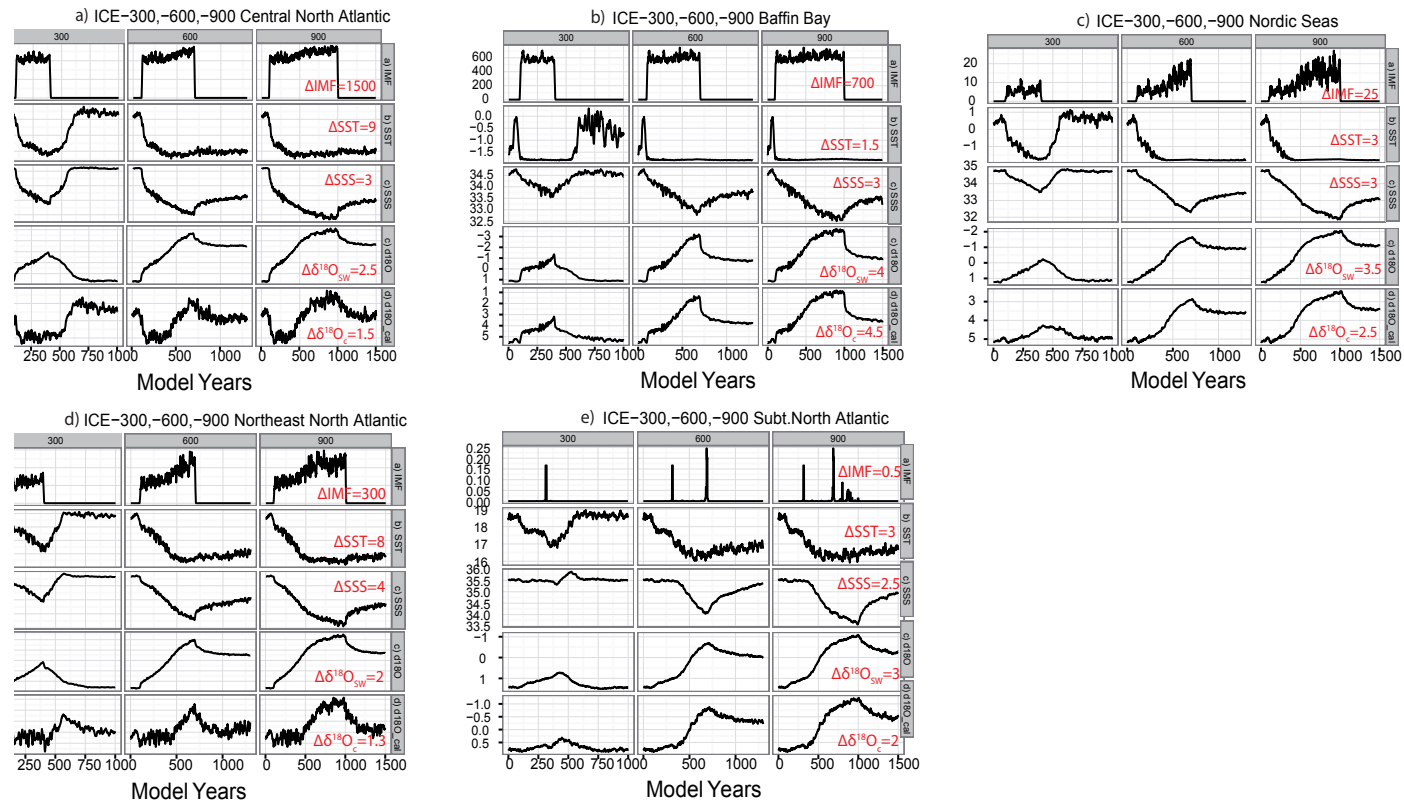

Figure 9. $1^{\text {st }}$ column: ICE-300, $2^{\text {nd }}$ column: ICE-600, $3^{\text {rd }}$ column: ICE-900; $1^{\text {st }}$ row: modeled Iceberg Melt Flux $\left(\mathrm{IMF}, \mathrm{m}^{3} \mathrm{~s}^{-1}\right), 2^{\text {nd }}$ row: modeled sea surface temperature $\left(\mathrm{SST},{ }^{\circ} \mathrm{C}\right), 3^{\text {rd }}$ row: modeled sea surface salinity (SSS, $\mathrm{psu}) ; 4^{\text {th }}$ row: simulated $\delta^{18} \mathrm{O}_{\text {seawater }}$ at the surface $\left(\delta^{18} \mathrm{O}^{\text {sw }}, \% o\right), 5^{\text {th }}$ row: simulated $\delta^{18} \mathrm{O}_{\text {calcite }}\left(\delta^{18} \mathrm{O}^{\mathrm{c}}\right.$, permil); (a) Central North Atlantic region $40-25^{\circ} \mathrm{W}, 45-55^{\circ} \mathrm{N}$; (b) Baffin Bay region $60-45^{\circ} \mathrm{W}, 60-70^{\circ} \mathrm{N}$; (c) Nordic Seas region: $20^{\circ} \mathrm{W}-20^{\circ} \mathrm{E}, 65-75^{\circ} \mathrm{N}$; (d) Northeast North Atlantic region: $20^{\circ} \mathrm{W}-0^{\circ} \mathrm{E}, 50-65^{\circ} \mathrm{N}$; (e) subtropical North Atlantic region: $45-35^{\circ} \mathrm{W}, 20-35^{\circ} \mathrm{N}$; the red values correspond to the maximum change 
Clim. Past Discuss., doi:10.5194/cp-2016-31, 2016

Manuscript under review for journal Clim. Past

Published: 17 March 2016

(c) Author(s) 2016. CC-BY 3.0 License.

a) NA87-22

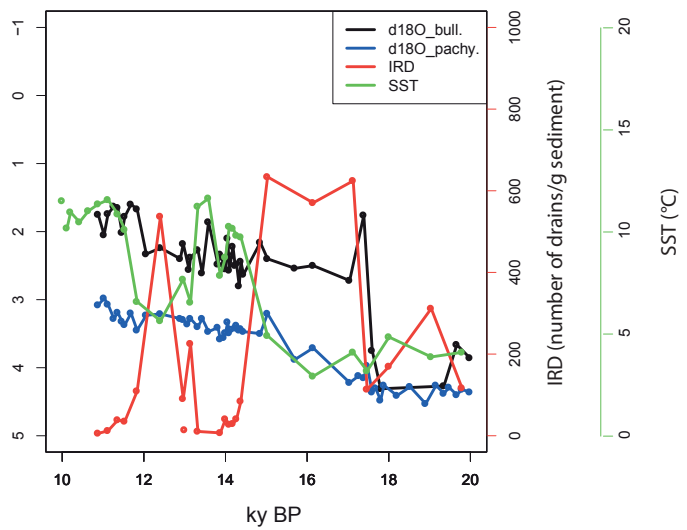

C) $\mathrm{CH} 69-\mathrm{K} 09$

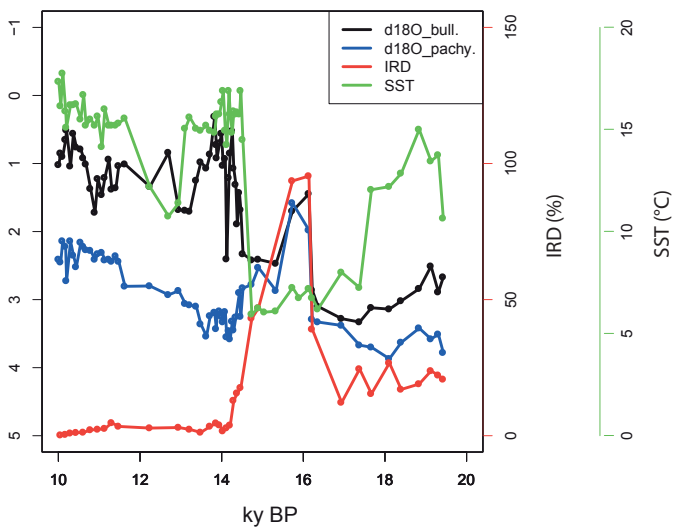

b) ENAM93-21

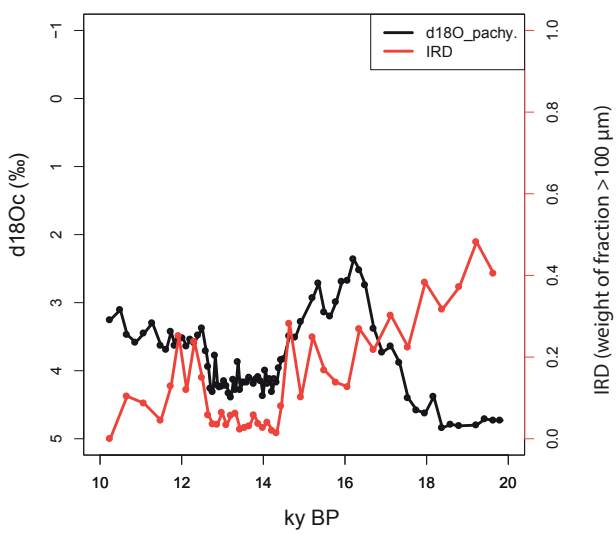

d) KNR31-GPC5

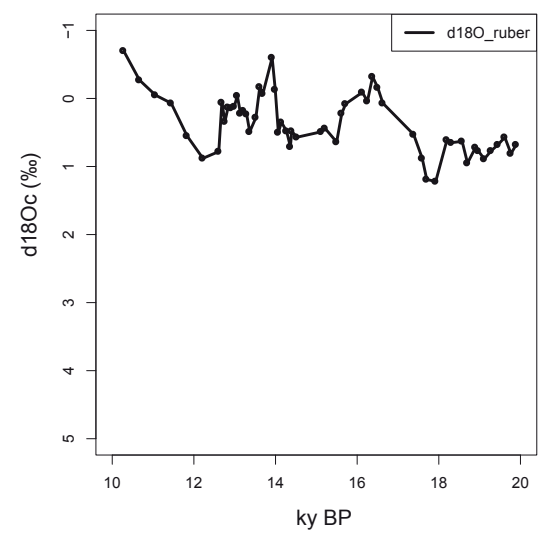

Figure 10. (a) core NA87-22 G. bulloides and N. pachyderma s. $\delta^{18} \mathrm{O}_{\text {calcite }}$ (Vidal et al., 1997), IRD data (number of grains per g dry sediment) (Elliot et al., 2002) and annual mean sea surface temperature computed as the average between reconstructed winter and summer SST based on planktonic foraminifer abundances (Waelbroeck et al., 1998, 2001, 2006); (b) core ENAM93-21 N. pachyderma s. $\delta^{18} \mathrm{O}_{\text {calcite }}$ and IRD data (weight of fraction > $100 \mu \mathrm{m}$; Rasmussen et al. (1996a, b, 1998); (c) core CH69-K09 G. bulloides and N. pachyderma s. $\delta^{18} \mathrm{O}_{\text {calcite }}$, IRD data (\%) and annual mean sea surface temperatures computed as the average between reconstructed winter and summer SST based on planktonic foraminifer abundances (Labeyrie et al., 1999; Waelbroeck et al., 1998, 2001); (d) core KNR31GPC-5 G. ruber $\delta^{18} \mathrm{O}_{\text {calcite }}$ (Keigwin et al., 1991; Keigwin and Boyle, 1999; Waelbroeck et al., 2011) 